\title{
The Vertical Distribution of Marine Macroplankton. V. The Distribution of Animals Caught in the Ring-trawl in the Daytime in the Plymouth Area.
}

By

F. S. Russell, D.S.C., B.A.,

Assistant Naturalist at the Plymouth Laboratcry.

With 11 Figures in the Text.

CONTENTS.

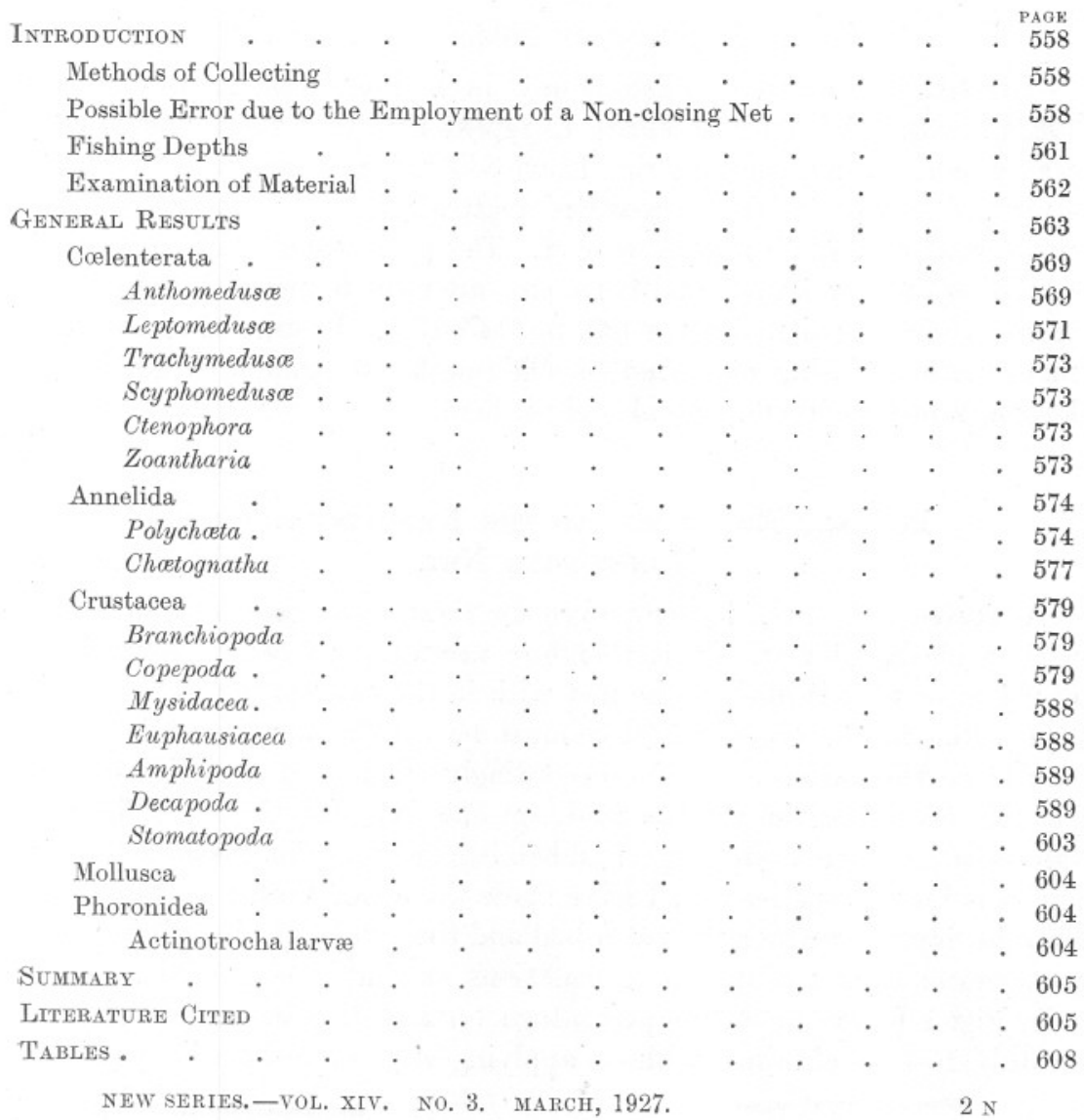




\section{INTRODUCTION.}

Between April 2nd and August 6th, 1925, a number of serial collections were made with the ring-trawl to determine the vertical distribution of the pelagic young of teleostean fish. The details of the young fish distribution have already been published (23), and it is with the remaining plankton animals taken in these collections that this paper deals.

I should like to take this opportunity of expressing my thanks to Dr. E. J. Allen, F.R.S., and other members of the staff of this Laboratory, for much helpful criticism and advice, especially to Dr. M. V. Lebour for assistance in the identification of many species. I also wish to thank Capt. V. Lord and the crew of the s.s. Salpa for their unfailing help when collecting at sea.

\section{Methods of Collecting.}

The details of methods of fishing have been given in the previous paper (23, p. 102). It is only necessary to repeat here that the net employed was a non-closing, stramin ring-trawl (diameter at mouth, 2 metres; length, 6 metres), with depth-recorder attached. All the stations were made in depths of 50 metres or over. The positions of stations, details of fishing times, weather conditions, etc., are to be found in the Appendix to the above-mentioned paper (23, pp. 145-151). Results of one station made with a closing metre-net of silk (mesh, 40 strands to the inch; length, 2 metres $60 \mathrm{~cm}$.) are also given here.

\section{Possible Error due to the Employment of a Non-closing Net.}

As stated above, the net employed for these researches was not fitted with a closing device. It is therefore necessary to obtain some idea of the error that is likely to be met with in the catches from the deeper layers due to the organisms that must be caught as the net is being hauled to the surface. I have accordingly attempted to estimate the possible errors for the catches made on one day, July 16th, 1925. On this occasion there were large numbers of Calanus finmarchicus taken, and it is for this species that I have made the estimations: on this date also the depths at which the net fished and times taken to haul it in were most suitable for making the calculations as simple as possible.

In Fig. 1 I have given the percentage vertical distribution of Calanus on July 16th as obtained without applying any corrections for possible 
errors (unbroken lines) : in the same figure I have also superimposed the vertical distribution that is given when corrections have been made for errors due to the non-closing of the net (broken lines). It can at once be seen that the uncorrected distribution diagram differs slightly from that obtained after the application of corrections in that, as is to be expected, the corrected percentages in the upper layers are slightly larger than the uncorrected, and, conversely, slightly smaller in the deeper layers. At the same time it is also obvious that the differences are in no degree great

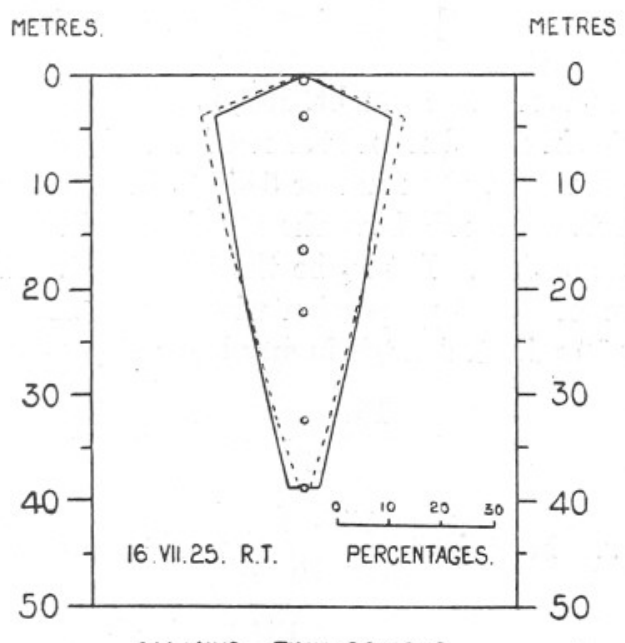

CALANUS FINMARCHICUS.

FIG. 1.-Diagram showing percentage vertical distribution of Calanus finmarchicus on July 16th, 1925. In this figure the unbroken line (-) represents the vertical distribution, as shown by the actual catches, and the broken line $(. .$.$) the same after$ correction for possible error due to the employment of a non-closing net.

enough to alter the true significance of the vertical distribution, as shown by uncorrected figures. To correct all catches for all species would, therefore, involve unnecessary waste of time and labour; in consequence all the distribution diagrams and tables are composed of the actual catches made by the net, and I think we can safely conclude that any errors due to the non-closing of the net are for our purposes negligible, at any rate when the animals are fairly numerous.

I give below the method by which the corrections given in Fig. 1 were obtained : in this case it was necessary to assume that the curves between each depth point on a distribution diagram are straight lines. 


\section{ACTUAL UNCORRECTED RESULTS.}

Average depth at
which hauls were
made, in metres.
Surface
4
$16 \cdot 5$
22
32
38

Approximate time
taken to haul in
net, in minutes.
0 minutes
$\frac{1}{4} \quad$,
$1 \quad$,
$1 \frac{1}{2} \quad$,
$2 \quad$,
$2 \frac{1}{2} \quad$,
Total catches of Calanus caught in 10 minute hauls plus time taken to reach the surface.

$\begin{array}{rr}157 & 0 \cdot 9 \% \\ 5450 & 33 \cdot 4 \% \\ 4140 & 25 \cdot 4 \% \\ 3420 & 21 \cdot 1 \% \\ 2070 & 12 \cdot 7 \% \\ 1040 & 6 \cdot 4 \%\end{array}$

At the surface the number caught, 157, is correct, because the haul is exactly 10 minutes in duration and the net immediately leaves the water.

At 4 metres, however, the number 5450 is incorrect, the net having fished for $\frac{1}{4}$ minute over and above the 10 minutes, in the layers between 4 metres and the surface. Let $\mathrm{x}_{4}$ be the true catch. If the number of Calanus increase in direct proportion with depth between the surface and 4 metres, a 10 minutes' catch in any layer above 4 metres would be

$$
\begin{gathered}
\frac{157+\mathrm{x}_{4}}{2} \\
\therefore \quad \text { in } \frac{1}{4} \text { minute } \frac{157+\mathrm{x}_{4}}{2 \times 10 \times 4} \text { would be taken. } \\
\text { Now } \mathrm{x}_{4}=5450-\left(\frac{157+\mathrm{x}_{4}}{80}\right)=\mathbf{5 3 8 1 .}
\end{gathered}
$$

The number caught, therefore, between the surface and 4 metres as the net is hauled up is

$$
5450-5381=69 .
$$

Again, let $\mathrm{x}_{16 \cdot 5}$ represent the true catch obtained at 16.5 metres. The net took 1 minute to reach the surface ; it was, then, fishing approximately for $\frac{3}{4}$ minute between 16.5 and 4 metres, and for $\frac{1}{4}$ minute between 4 metres and the surface.

We have already found that in $\frac{1}{4}$ minute between 4 metres and the surface 69 specimens would be caught; it is necessary, therefore, to find now how many would be taken between 16.5 and 4 metres in $\frac{3}{4}$ minute.

$$
\begin{gathered}
\text { This will be }\left(\frac{5381+\mathrm{x}_{16 \cdot 5}}{2 \times 10}\right) \frac{3}{4} \\
\therefore \quad \mathrm{x}_{16 \cdot 5}=4140-\left(\frac{5381+\mathrm{x}_{16 \cdot 5}}{2 \times 10}\right) \frac{3}{4}-69=3729 .
\end{gathered}
$$


Let $\mathrm{x}_{22}$ be the true catch at 22 metres : the net took $1 \frac{1}{2}$ minutes to reach the surface; say-for convenience- $\frac{1}{2}$ minute between 22 and $16.5 \mathrm{~m}$. and 1 minute between $16.5 \mathrm{~m}$. and the surface. Between $16.5 \mathrm{~m}$. and the surface we saw from the previous haul that in 1 minute $4140-$ $3729=411$ specimens were caught.

Now between 22 and $16.5 \mathrm{~m}$. in $\frac{1}{2}$ minute $\left(\frac{3729+\mathrm{x}_{22}}{2 \times 10}\right) \frac{1}{2}$ would be taken

$$
\therefore \quad \mathrm{x}_{22}=3420-\left(\frac{3729+\mathrm{x}_{22}}{2 \times 10}\right) \frac{1}{2}-411=2845 .
$$

Similarly let $\mathrm{x}_{32}$ be the correct catch at $32 \mathrm{~m}$., and say that the net on its upward journey took $\frac{1}{2}$ minute from $32-22 \mathrm{~m}$. and $1 \frac{1}{2}$ minutes from $22 \mathrm{~m}$. to the surface. Then,

$$
\mathrm{x}_{32}=2070-\left(\frac{2845+\mathrm{x}_{32}}{2 \times 10}\right) \frac{1}{2}-(3420-2845)=1389 .
$$

Similarly at $38 \mathrm{~m}$., allowing $\frac{1}{2}$ minute to haul from 38 to $32 \mathrm{~m}$., the whole period to the surface being $2 \frac{1}{2}$ minutes, we find

$$
\mathrm{x}_{38}=1040-\left(\frac{1389+\mathrm{x}_{38}}{2 \times 10}\right) \frac{1}{2}-(2070-1389)=\mathbf{3 1 6} .
$$

So that the approximate corrected figures will be :-

$\begin{array}{lrr}\text { Surface } & 157 & 1 \cdot 1 \% \\ 4 \text { metres } & 5381 & 39 \cdot 0 \% \\ 16 \cdot 5, & 3729 & 27 \cdot 1 \% \\ 22 \quad, & 2845 & 20 \cdot 6 \% \\ 32 \quad, & 1389 & 10 \cdot 0 \% \\ 38 \quad, & 316 & 2 \cdot 2 \%\end{array}$

\section{Fishing Depths.}

The graphic depth-recorder, kindly lent by Admiralty authorities, was employed to obtain the depths at which the net was fishing. The records obtained on April 8th and 29th, May 19th, June 17th, 18th, and 19th, have already been published (23, p. 104, and 24, pp. 392, 393). I give here in Fig. 2 tracings obtained on five further dates, July 1st (i.) and (ii.), 16th, and 29th, and August 6th, 1925 .

The average depths for each haul have been obtained by taking the depths at 10 or more equidistant points along each curve and finding the mean. In Station 26, July 29th, after haul Number VI the bucket containing the catch was lost: another haul was therefore taken, but the clock was not wound up, so that the maximum depth of the haul only was recorded, i.e. $31 \mathrm{~m}$. In the tables the average depth of this haul has been put at about 29 metres. 
METRES. METRES
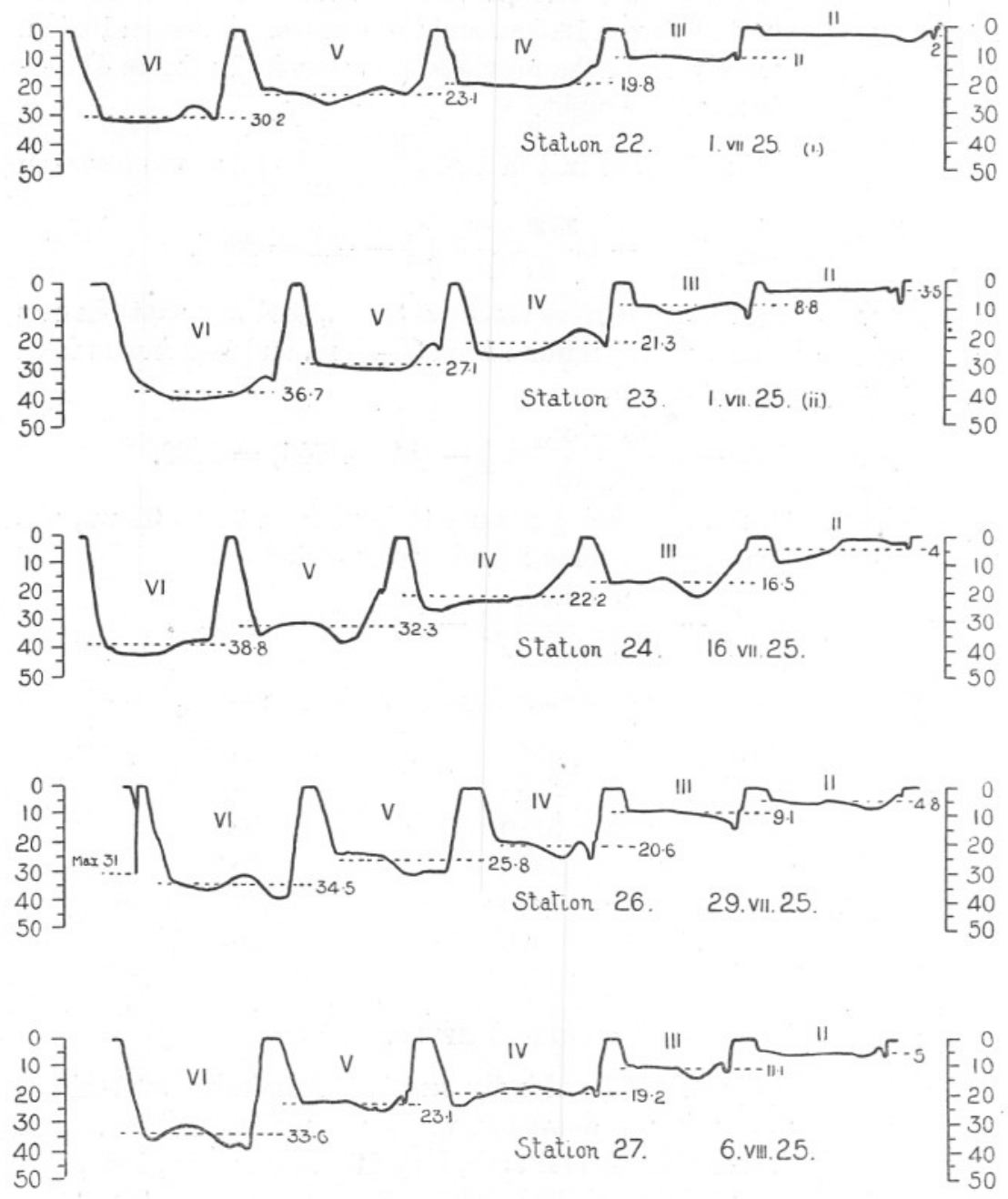

FIg. 2.-Five series of curves, obtained on the dates given, showing the path of the net through the water for each haul. (The surface hauls are no included.) The net enters the water on the right-hand side of each curve. The dotted lines indicate the calculated "average depth." (The differences in the lengths of the curves are due to irregularities in the speed of the recorder clock and not to errors in timing.)

\section{Examination of Material.}

Before any sorting was undertaken each catch was placed in a tall measuring jar and the volume noted after being allowed to settle for 24 hours. From each catch were then picked out all species that on 
account of their size, or shape, or colour, could be easily distinguished : at the same time those species that were comparatively rare and only occurred in small numbers were picked out as carefully as possible, because the error in sampling might tend to obscure the true distribution of these species when their numbers were so small. The following species were dealt with in the above manner, and all numbers given in the tables for these species are therefore obtained by complete counts:-

Turris pileata, Cosmetira pilosella, Saphenia gracilis, Cyanea capillata, Aurelia aurita, Slabberia halterata, Liriope sp., Peachia sp., Anomalocera Patersoni, Caligus rapax, Leander sp. larvæ, Alpheus ruber larvæ, Pontophilus spinosus larvæ, Palinurus vulgaris Phyllosoma larvæ, Pagurid sp. Glaucothöe larvæ, Axius styrhinchus larvæ, Nyctiphanes Couchii adults and young, Mysids, Hyperiid amphipods, Squilla Desmaresti Alima larvæ, Tomopteris helgolandica, Pceilochatus serpens larvæ, Arachnactis larvæ.

The remaining species were sampled by the method described in a previous publication ( 22, p. 776$)$, the catch being made up to 5000 c.c. in a wide-mouthed bell-jar and 500 c.c. removed while the mass was being stirred. In a few cases when the catches were unusually small they were only made up to 2500 c.c. and 500 c.c. samples withdrawn, so that $\frac{1}{5}$ instead of $\frac{1}{10}$ of the whole catch was counted. In extremely small catches, such as occurred at times in the surface layers, all the organisms were counted without sampling.

\section{GENERAL RESULTS.}

I give in the last column of Tables III and IV (at end of paper) the actual volumes of each catch obtained by allowing them to settle for 24 hours: although very misleading on account of the different-sized animals that compose the collections, these volumes show on the whole the fact that the preponderance of the plankton sampled by the ring-trawl occurred in the deeper layers, the main exceptions being on April 8th and May 19th (i.), when it can be seen that the large surface volumes are caused by swarms of zoeas and megalopas of Corystes cassivelaunus. In the last column but one of Tables III and IV are given the total numbers of organisms caught on each occasion, and their percentage vertical distribution is given in Fig. 11, p. 600 . These figures show clearly that generally in the daytime, at any rate during the months of May, June, and July, the general mass of the plankton animals sampled by the ring-trawl live in the deeper layers around 25 to 30 metres, and that a gradual lessening in numbers is shown from this depth towards the surface, the upper 5 or 10 metres being very sparsely populated. At the same time there are indications that in early April, and in August under foggy weather conditions, there are nearly 
as many organisms to be found close to the surface as in the deeper levels ; the number of observations made at these times of the year are, however, too few to warrant one to draw conclusions. Now this impression is, of course, that of the vertical distribution of all the animals together, and is, in fact, the sum of a number of different types of vertical distribution shown by the various individual species.

From the information so far obtained it is not safe to make absolutely definite conclusions, but general indications would appear to give probability to the following statements :-

1. Some species have an optimum depth at which the majority of that species live, while a certain vertical range of distribution is shown within the confines of which the same species more or less keeps. These depths may vary for different aged animals and for the two sexes in the same species.

2. Certain species can be chosen that, when compared, will give a gradual descending series of the region of their maximum abundance. During May, June, and July a marked consistency is shown in the order of this variation of depth distribution, so that from day to day the species exhibit the same differences in the region of their maximal abundance with relation to each other.

3. The actual depths at which the regions of greatest abundance occur may vary for each species from day to day. Fig. 3, for instance, shows that Calanus finmarchicus, Upogebia larvæ, and Turris pileata, had their regions of maximum abundance confined within the limits of 6.5 and 22 metres on May 19th, 11.4 and 34 metres on June 4th, and 3 and 22.5 metres on July 16 th, but at the same time the sequence shown by these three species in the order of their depth distribution did not vary.

4. Certain species may exhibit sudden marked changes in the depth of their maximum abundance; Sagitta bipunctata, while preferring the deeper layers below 20 or 25 metres in April, May, and June, suddenly appeared more abundantly much nearer the surface at the end of July and beginning of August. Similarly, Tomopteris helgolandica, while apparently living very close to the bottom during April, May, and June, like Sagitta, came up into the upper water layers at the end of July and beginning of August. The significance of this behaviour is not known. The weather in July and August when the change was apparent was extremely foggy, which very probably may have had an influence: at the same time, with Tomopteris at any rate, there seems a possibility that spawning may have been a factor of importance. Many more observations of this kind are required before the behaviour can be understood. 


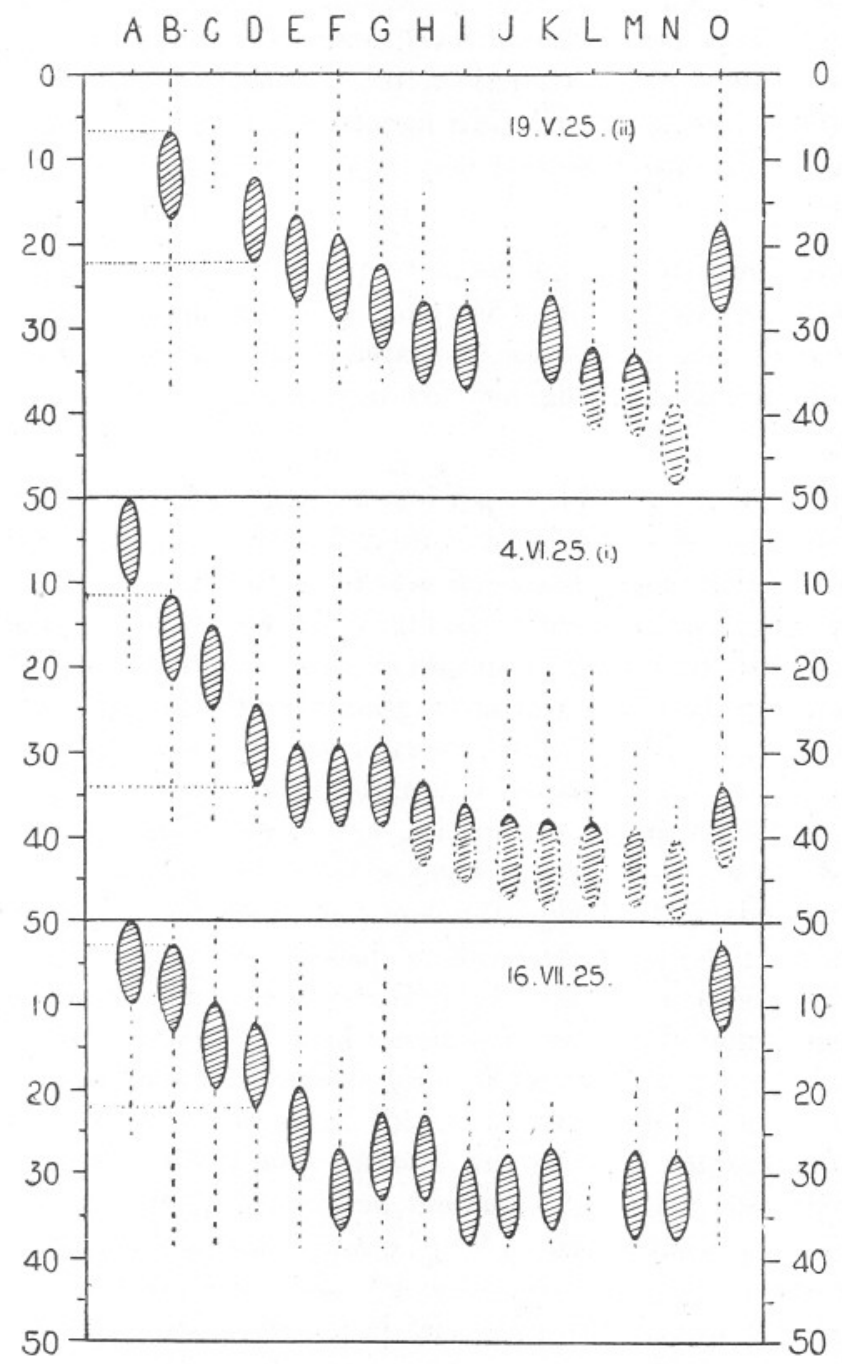

FIG. 3.-Diagram to show the vertical distribution of the undermentioned animals on the three dates given. The shaded ellipses show the region of maximum abundance and the vertical broken lines the total range of vertical distribution for each species. The depths are in metres.

A. Anomalocera Patersoni. B. Calanus finmarchicus. C. Upogebia sp. larvæ. D. Turris pileata. E. Porcellana sp. zoea. F. Galatheid larvæ. G. Pandalid larvæ. H. Pagurid larvæ. I. Cosmetira pilosella. J. Candacia armata. K. Crangonid larvæ. L. Pontophilus spinosus larvæ. M. Apherusa sp. N. Tomopteris helgolandica. O. Sagitta bipunctata. 
5. Other species, such as Phialidium, appear very inconsistent in their vertical distribution, being most abundant one day at one depth and the next day at a very different level, without any apparent important change occurring in the external factors. Whether such signifies their indifference to the various physical factors met with at different depths, or whether distribution of food may control their movements remains to be discovered.

6. The majority of the species met with in the ring-trawl collections showed a preference for the layers from about 20 metres downwards in sunny weather, the species that appeared to like the surface and upper highly illumined layers being very few in number.

It is obviously not possible to put forward any scheme to cover broadly the various types of vertical distribution shown by the different species, dealt with in this paper, based on actual depth units, as we have seen that these vary from day to day. In Fig. 3 I have shown diagrammatically the vertical distribution for 15 species on three different days, May 19th, June 4th, and July 16th. In this diagram the vertical range of any one species is given by a broken line, and the region of maximal abundance, as near as it can be estimated, is indicated by a shaded ellipse. From the actual catches of certain species, e.g. Pontophilus spinosus larvæ, Crangonid larvæ, etc., it seems permissible to assume that the region of maximal abundance lies below the depth at which the deepest haul was made, and that the upper limits of its distribution alone were sampled: in these cases I have indicated by dotted ellipses the probable depth at which their region of greatest abundance may be located. The diagram, then, shows very strikingly that as one goes deeper so new animals become abundant. I have also inserted in this figure the vertical distribution of Sagitta bipunctata, showing the apparent change that occurred in the depth at which it was most abundant between June 4th and July 16th. In a previous publication (25, p. 416) I gave the actual percentage vertical distribution for ten species on June 4th, July 1st, and July 16th. In that diagram I placed certain species in a slightly different order from that given in Fig. 3 of this paper. The species in question were Crangonid larvæ, Candacia armata, and Cosmetira pilosella; the point is, however, of slight importance, as from the few observations obtained it is difficult to state whether these three species show any difference in their vertical distribution. Careful study of the question points to the fact that Crangonid larvæ probably occur slightly deeper than either Cosmetira or Candacia when the actual numbers rather than percentages are judged.

Although I have pointed out that one cannot base a scheme for the 
vertical distribution of different species on actual depth units, I give below a list showing their vertical distribution with arbitrary depth units inserted, in order to make possible an impression of the distribution of many of the different animals taken in the ring-trawl with relation to each other. It must, however, be firmly understood that these depths are not fixed, and that we are here dealing only with the species captured by the ring-trawl and the various sizes of those species that it samples, for the months, end of April, May, June, July, and beginning of August.

Surface. Anomalocera Patersoni (but deeper on August 6th).

Corystes cassivelaunus, late zoeas and megalopas on occasion.

Leander sp. larvæ (as well as in deeper layers).

Abundant below 10 metres. Calanus finmarchicus.

\begin{tabular}{|c|c|c|c|c|}
\hline " & " & 12 & , & $\begin{array}{l}\text { Upogebia sp. larvæ : Alpheus ruber larvæ ; } \\
\text { Squilla Desmaresti alima larvæ. }\end{array}$ \\
\hline ," & ", & 15 & , & Turris pileata: Axius styrhinchus larvæ. \\
\hline , & , & 18 &, & Porcellana sp. zoea. \\
\hline ", & , & 20 & , & $\begin{array}{l}\text { Caligus rapax; Galatheid sp. larvæ: } \\
\text { Pandalid larvæ; Callianassa subterranea } \\
\text { larvæ. }\end{array}$ \\
\hline " & , & 25 & ," & $\begin{array}{l}\text { Saphenia gracilis; Cosmetira pilosella; } \\
\text { Sagitta bipunctata (until end of July } \\
\text { and beginning of August); Candacia } \\
\text { armata; Apherusa sp.; Pagurid larvæ. }\end{array}$ \\
\hline " & , & 30 & " & $\begin{array}{l}\text { Steenstrupia rubra; Tomopteris helgo- } \\
\text { landica (until end of July and beginning } \\
\text { of August); Crangonid larvæ; Ponto- } \\
\text { philus spinosus larvæ : Palinurus vul- } \\
\text { garis phyllosoma larvæ; Galatheid } \\
\text { post-larvæ; Upogebia post-larvæ; Pa- } \\
\text { gurid glaucothoë larvæ. }\end{array}$ \\
\hline
\end{tabular}

Occurring irregularly at all depths: Phialidium sp.; Obelia sp.; Pleurobrachia pileus (?).

I would emphasize again that the above scheme is not to be taken too literally, as it is obviously extremely difficult to draw hard and fast lines between the distributions of many species ; it is, however, in the writer's opinion, a fairly correct impression gained by repeated sorting of material and careful perusal of the figures. There are, of course, many species not mentioned above occurring in the catches, but generally in too small numbers to draw conclusions from. Crab zoeas also are not included, as 
they comprise such a variety of species; identification of certain species, e.g. Ebalia, has shown that the various species that go to make up the mass of crab zoeas have different vertical distributions, as, indeed, is only to be expected.

No attempt is made in this paper to correlate results with the factors that may control the vertical distribution of the animals dealt with. It is merely intended as a description of the actual distribution exhibited by the various species in this region on certain days between April and August as revealed by catches obtained with the ring-trawl. Although containing apparently a very large mass of information, it must be remembered that for each species the observations are few, being confined mostly to two or three in each month. In 1926 a similar series of observations has been made, and it may be possible that with the combined results of the two years, 1925 and 1926, correlations may make themselves apparent.

One or two points are indicated, the evidence for which may or may not, as yet, be sufficient to be significant. It is noticeable that in many cases the deeper an animal normally lives the less change it seems to show in its vertical distribution under changing seasonal and weather conditions. As an example we may cite Calanus finmarchicus, Upogebia larvæ, Pandalid larvæ, Cosmetira pilosella, and Crangonid larvæ. While Calanus and Upogebia larvæ show quite distinct alterations in level under sunny or dull conditions (Figs. 5 and 9), Pandalid larvæ show a much less marked change (Fig. 9), and Cosmetira and Crangonid larvæ show apparently no alterations in level (Figs. 4 and 9). The occurrence of many species at the surface on May 19th, when a large swarm of Corystes megalopas was in the upper layers, is also of interest.

In the succeeding pages the different species are dealt with in detail, and short notes are also appended on the seasonal distribution of certain species. Taken on the whole the ring-trawl collected plankton reached a very high value on. May 19th, and was then somewhat scarce until, towards the end of July, there was a further great increase in numbers, due especially to large swarms of Calanus and Sagitta. It is interesting that these two peaks in the abundance of plankton appear slightly before two small increases in the phosphate content in the summer of that year.

In order to save space the actual figures for each species on the different days are given in the Tables 2,3 , and 4 at the end of the paper. The species caught in the metre net (Table 2 ) are arranged roughly in the order in which they become abundant as the net fishes deeper, and the Table thus emphasizes the gradual appearance of certain species in the lower layers, which were absent nearer the surface. 


\section{COELENTERATA.}

\section{ANTHOMEDUSA.}

\section{Steenstrupia rubra Forbes.}

This medusa did not appear in the collections until June. From then onwards it was not common; but occurred as follows :-

$$
\begin{aligned}
& \text { June 4th, } 20 \text { individuals at } 31.8 \text { metres. } \\
& \text { "17th, } 10 \quad \text {, } 48 \cdot 8 \text {, } \\
& \text {, 18th, } 6 \text {, } 31.4 \text {, } \\
& \text {," 19th, } 9 \text { ", } 23 \cdot 3 \text {, } \\
& \text { July } 16 \text { th, } 2 \text { at } 22 \cdot 2 \mathrm{~m} \text {. : } 1 \text { at } 32 \cdot 3 \mathrm{~m} \text {. : and } 1 \text { at } 38.8 \mathrm{~m} \text {. }
\end{aligned}
$$

From the above figures it would appear that Steenstrupia was a deepliving member of the plankton in this region, occurring always below 20 metres and generally below 30 metres, and being absent in the layers above these depths. On July 15 th and 16th, 1924, this species was also taken mostly below 20 metres in the daytime, none being caught above a depth of $18 \mathrm{~m}$. (22, p. 781). The fact that in July, 1924, the numbers increased at night, a phenomenon repeated during experiments made on two nights in June, 1925 (not yet published), would suggest that generally they were mostly distributed in deeper layers than those sampled by the net in the daytime.

Seasonal distribution. In Tables 3 and 4 it can be seen that none of these medusæ were captured until June 4th, and that after July 1st no more were taken. There is, however, risk in drawing conclusions for this species, because, as indicated above, it is possible that they live mostly in the deeper unsampled layers.

\section{Slabberia halterata Forbes.}

This medusa occurred only once, on June 19th, when one specimen was caught in the haul at $23 \cdot 3$ metres.

\section{Stomatoca dinema L. Agassiz.}

Only seven specimens of this medusa were obtained. On June 17th, one at $29.8 \mathrm{~m}$; on June 19th, two at $23.3 \mathrm{~m}$; on July 1st, one at $21.3 \mathrm{~m}$. and one at $27.1 \mathrm{~m}$.; on July 16th, one at $4 \mathrm{~m}$. ; and on July 29 th, one at 29 metres. This species would appear then usually to have preferred the layers below 20 metres. 

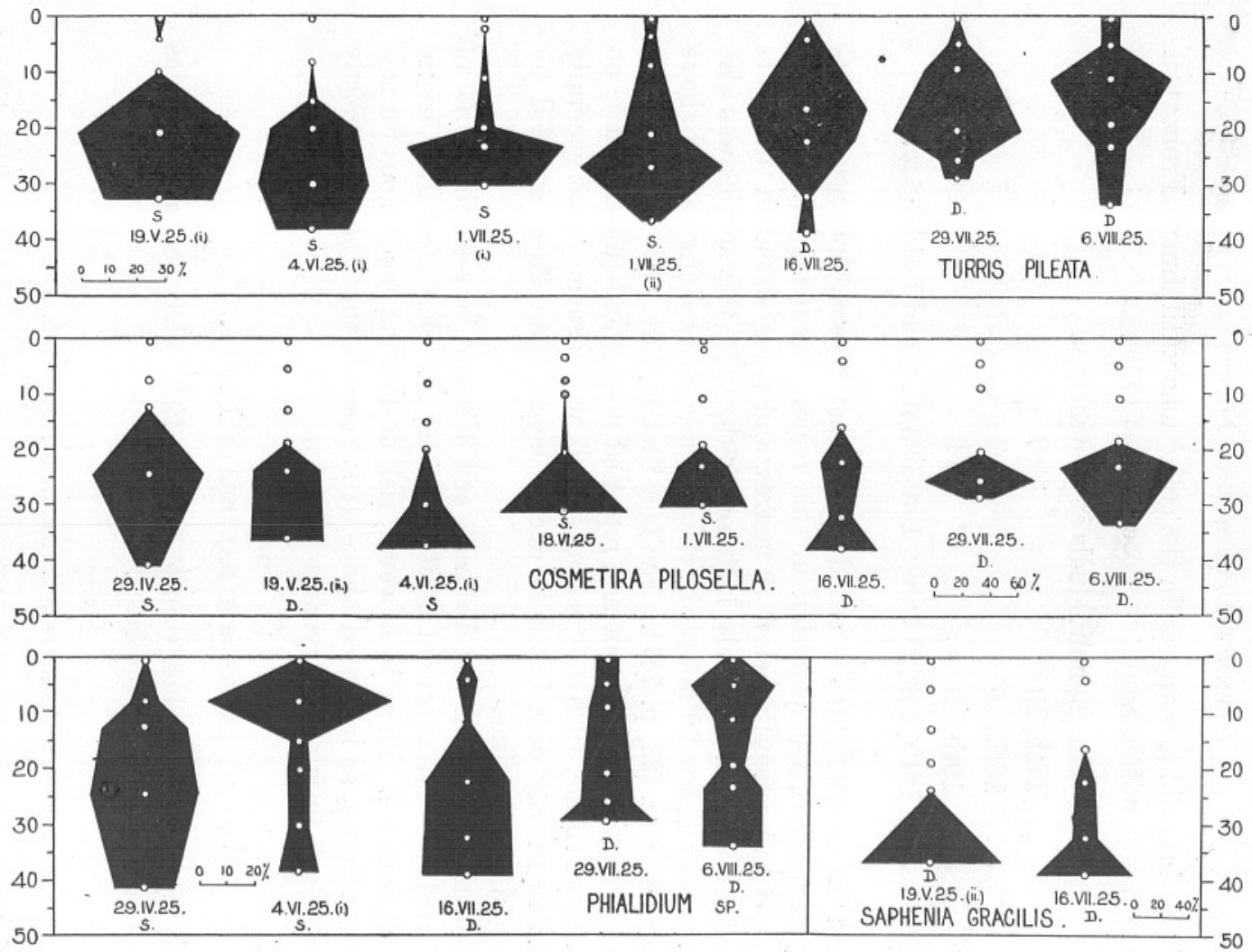

FIG. 4.-The percentage vertical distribution of Turris pileata, Cosmetira pilosella, Phialidium sp., and Saphenia gracilis on the dates given. The white spots and black circles indicate the average depths at which hauls were taken. $\mathrm{S}=$ Sunshine. $\mathrm{D}=$ Dull. Note that the percentage scale for Saphenia and Cosmetira is half that of the other two species, 


\section{TURRIS PILEATA (Forskal).}

Turris pileata became abundant in the plankton in May.

From then until July 1st its region of maximum abundance on sunny days, at position A, lay between 20 and 30 metres. It was comparatively rare in the hauls above 20 metres. At the Station L4, however, which is about 4 miles nearer the shore, they were slightly higher in the water on May 19th, June 4th, and July 1st.

On July 16th and 29th, and August 6th, they were considerably higher in the water at position A than earlier in the year (Fig. 4). This may have been correlated with the fact that on these days the weather was. very dull and foggy. On June 19th, 1925, nearer L4 than A, the vertical distribution was almost identical with that on July 15th and 16th, 1924. (See 25, Fig. 6, p. 432, and 22, Fig. 2, p. 783.)

Seasonal distribution. Turris was present on almost all the days on which collections were made, but was most abundant in May, June, and July and the beginning of August. The largest catches occurred on May 19 th at L4, but on the same day at A the numbers taken were very much smaller, showing that at L4 a swarm was probably encountered. The next largest catch occurred on July 1st.

\section{Bougainvillea sp.}

When present these medusæ were very rarely caught in the water layers. above 18 metres, the region of maximum abundance lying at about 25 to 30 metres on June 4 th and July 16 th, on which days it was most numerous.

\section{LEPTOMEDUS压.}

\section{Obelia sp.}

The occurrence of this species, probably Obelia nigra, was somewhat irregular. On the occasions on which it was present it did not appear to show any definite preference for different levels in its vertical distribution. Although from the ring-trawl collections it would appear to have. been most numerous below 20 metres, on July 16th, when the ring-trawl catches showed the greatest number at $22 \cdot 2$ metres, hauls in the same locality with the silk closing metre net showed the largest catch at 6.5 metres, indicating that the species is not consistent in its depth distribution, unless there was size selection by the two nets, the catches of the ring-trawl representing the largest medusæ. This, however, was unfortunately not noticed at the time, and the samples have since been thrown away. 
Seasonal distribution. Swarms were apparently met with on April 22nd, July 16 th and 29 th ; on the remaining days on which collections were made few or none were caught in the ring-trawl.

\section{Phialidium sp.}

The vertical distribution of this species, probably mostly $P$. hemisphericum, was very irregular, the region of maximum abundance lying sometimes up at the 10-metre level and at other times considerably deeper (Fig. 4). Like Obelia, this species was shown to be most abundant below 20 metres with the ring-trawl on July 16th, and yet the largest catch occurred at $2 \cdot 7$ metres with the silk metre net.

Seasonal distribution. Phialidium was present in most catches throughout the period of collecting, but there was a very pronounced maximum of abundance on. July 16th, and the species was still very numerous on July 29th and August 6th.

\section{Cosmetira pilosella Hartlaub.}

This medusa is evidently a deep-living member of the plankton community in this locality in the daytime. Its region of maximum abundance always lay below the 20 -metre level and generally deeper (Fig. 4). The type of distribution shown by this species, which apparently lives within a very narrow vertical range, has been discussed in a previous paper (25, pp. 423 and 428). So consistent is this form in its vertical distribution and so rarely is it taken in the layers above 20 metres, and then only in very small numbers, that its existence in fair abundance in a day time catch in oftshore waters would seem to be a very reliable indication that the net has been fishing below 20 metres. On account of its very distinctive appearance and large size it gives a very characteristic aspect to collections from the deeper levels.

Seasonal distribution. Cosmetira was present throughout the collecting period, except on April 2nd and 8th.

\section{Saphenia gracilis (Forbes and Goodsir).}

This medusa was never very abundant; the majority were, however, caught from below 20 metres (Fig. 4).

Seasonal distribution. Saphenia was present in small numbers in almost all the collections between April and August; the largest catch occurred on July 16th.

\section{ÆQuorea Forskalea Péron and Lesueur.}

Very young representatives of this species, between $\frac{1}{4}$ and $\frac{3}{4}$-inch in diameter, occurred occasionally. When present they were always taken from below 20 metres. 


\section{TRACHYMEDUSAE.}

Aglantha rosea Browne.

This species only occurred on two days, April 8th, when one was caught at $16.5 \mathrm{~m}$. and one at $25.3 \mathrm{~m}$. ; and on April $22 \mathrm{nd}$ at 22.1 metres.

\section{LIRIOPE sp.}

This species appeared only in the catches on August 6th, when 8 specimens were captured at $11.1 \mathrm{~m}$. ; one at $19.2 \mathrm{~m}$., and one at $23.1 \mathrm{~m}$ None were taken either at the surface or at 5 metres.

\section{SCYPHOMEDUSAE.}

Cyanea capillata Eschscholtz.

Small specimens of Cyanea between $\frac{1}{2}$ and $3 \frac{1}{2}$ inches in diameter were caught occasionally. They usually came from below 15 metres.

\section{CTENOPHORA.}

\section{Pleurobrachia pileus Fab.}

This ctenophore when present appeared rather inconsistent in its vertical distribution, being more or less irregularly distributed from the surface downwards. On the day on which most were caught, July 1st, the region of maximum abundance lay apparently between the surface and 15 metres.

Seasonal distribution. While being very scarce up till May 19th, from June 4th onwards Pleurobrachia was relatively abundant.

\section{ZOANTHARIA.}

Peachia sp. larvæ.

These larval anemones were not common in the collections. Their distribution is probably governed by the medusæ that carry them. It is a curious fact, however, that on May 19th 10 occurred in the surface haul, but there were no medusæ except for 5 Turris. There was, however, at the time a very large shoal of Corystes zoeas at the surface, which seemed to attract many other species to the surface.

Arachnactis Bournei Fowl.

These, the larvæ of Cerianthus Lloydii Gosse, occurred on two or three occasions generally below 20 metres. 


\section{ANNELIDA.}

\section{POLYCHÆTA.}

\section{TOMOPTERIS HeLgolandica Greef.}

Tomopteris was frequent at times in the collections. Individuals varied in size from about $4 \mathrm{~mm}$. upwards in length. McIntosh, in a recent paper (19), discusses the specificity of the small Tomopteris found in the North Sea. These forms, less than $12 \mathrm{~mm}$. in length, are characterised by the possession of a pair of small setigerous frontal cirri in front of the pair normally present in the full-grown. $T$. helgolandica; in all other respects they apparently accurately resemble this latter species. McIntosh quotes Carpenter and Claparède, who state that the young forms of $T$. helgolandica possess this additional pair of small cirri, the setigerous portions of which are thrown off when the development of the caudal region takes place, and the tubercle remaining gradually disappears. McIntosh says: "Some of the small forms, again, which were placed as undisputed examples of $T$. Catherina ( $T$. helgolandica), presented a knob or stump on the site of the first cirrus, so that the remarks of Carpenter and Claparède rest on fact, viz. that the first cirrus may occasionally be removed, though further investigations are necessary." McIntosh is, however, inclined to identify this small form with T. kefersteini of Greef, and, having seen an ovigerous female with two pairs of cirri, says, "On the whole, the evidence leans to the separation of $T$. kefersteini up to date, and it is a form widely distributed in European waters."

When discussing the vertical distribution it is necessary to know whether two species are being dealt with. I have accordingly examined a large number of Tomopteris with the following result :-

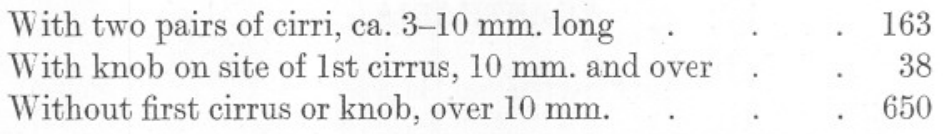

In view of the fact that I have never seen a specimen less than about $10 \mathrm{~mm}$. in length without the additional pair of cirri, and that I have found so many carrying small knobs or tubercles, indicating that the cirrus is caducous, I have regarded all individuals as belonging to one species, Tomopteris helgolandica Greef. Malaquin and Carin regard it as characteristic of many young forms to possess this first pair of cirri which are larval characters only in many species. They say $(20$, p. 4) : " L'organe est rudimentaire et il manque chez la forme adulte d'un certain nombre d'espèces." And again (p. 18): "D'autres caractères ne sont 
applicables qu'à des individus âgés, par example la présence ou l'absence de la première paire d'appendices sétigères, . . . . En effet, si le Tomoptère étudié est suffisamment jeune on observa la première paire d'appendices sétigères, même si le type adult n'en comporte pas."

I only obtained Tomopteris in abundance, in the daytime, on July 16th and 29th and August 6th : on all other occasions it occurred either singly or in very small numbers; most, however, were taken below 20 metres. On July 16th, when they were numerous, the majority also occurred below 20 metres, the maximum catch being at 32 metres. On July 29th the maximum was at $29 \mathrm{~m}$. ; the water below this depth was, however, not sampled: on this occasion Tomopteris was far more numerous also in the upper layers, above 20 metres, than previously (Fig. 5). It was noteworthy that the catch at 29 metres contained many very small specimens. On August 6th they were abundant at all depths from 33.6 metres up to 5 metres, but only one was captured right at the surface.

From an examination of these day results one would conclude that until July 16th Tomopteris was not abundant in the Plymouth region at all. On the nights of June 17th-18th and 18th-19th, however, similar series of observations were made, with the following results :-

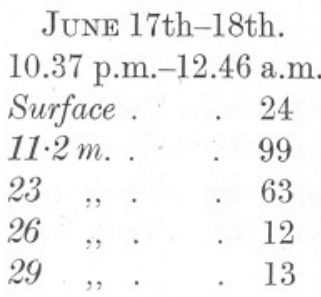

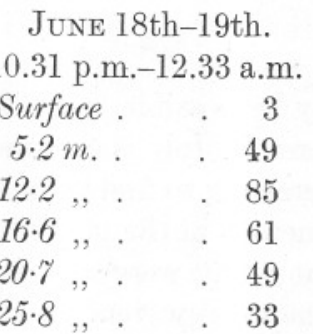

Thus, while on any day between April 2nd and July 16th the total of six catches never exceeded 34 (i. vii. 25 (i.)) in the daylight, on two nights in the middle of June the total numbers caught were 211 (5 hauls only) and 280 . These two catches, then, represent the same population as the 252 caught on July 16th, 300 on July 29th, and 290 on August 6th. This is somewhat disturbing, as it indicates that, in mid-June at any rate, although the daytime catches showed that Tomopteris was absent from the plankton, it was certainly present in the locality. On June 17th, on the afternoon before the night catches of 211 were made, only 3 specimens of Tomopteris were caught: on this occasion none were taken in the deepest haul, during which the net fished to a maximum depth of 52 metres, with an average of $48.8 \mathrm{~m}$., the bottom itself being at most at about 56 metres. From these results only one conclusion can be drawn : 
that is, that, on this day at any rate, Tomopteris was either lying on the bottom, or in the water layers immediately adjacent.

Until further observations are forthcoming then it would appear that from April until mid-July Tomopteris helgolandica lives in the daytime either on or very close to the bottom, and that in mid-July and August it comes up into the midwater layers with the rest of the plankton. It should be noted, however, that on the three days in. July and August when Tomopteris was abundant in the midwater layers the weather was extremely dull and foggy, which may signify that the lighting conditions, rather than the time of year, were responsible for their appearance above the bottom. A further observation of interest is, also, that on July 16th and 29th some of the worms were seen to be carrying eggs. The actual numbers were :-

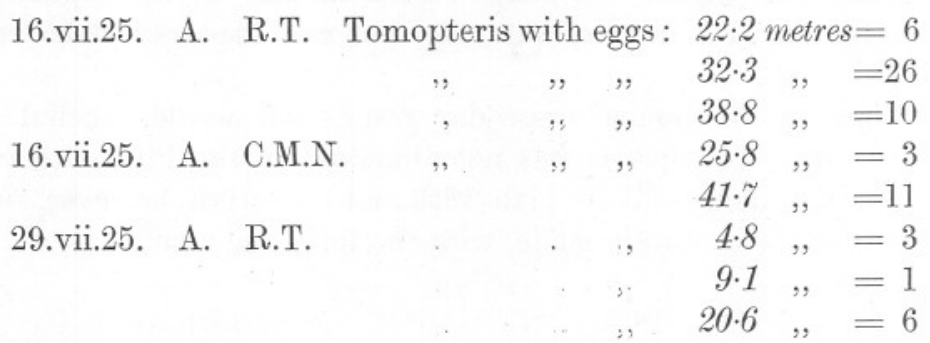

It may be possible, then, that this appearance in the upper layers of Tomopteris in July is in some way connected with their spawning habits. It is interesting to find that on July 15th and 16th, 1924, when they were also numerous in the plankton in the daytime (22, p. 788), I had made a note that many were carrying eggs.

For the deep waters off the Irish coast, Southern (2\%) says: "With reference to the vertical distribution of $T$. helgolandica, there are no signs of any correlation between its occurrence at certain depths and such factors as temperature, hour of the day, state of sexual maturity, etc. It has been taken at all depths from the surface to below 1000 fathoms."

Gough (8) says that on July 1st, 1903, " during the hottest part of the day the bulk of the Tomopteris was found near the bottom at 70 metres, only a very few being at 30 metres."

Seasonal distribution. The above results are of great importance when we consider the seasonal distribution of the species: it would appear that it is not possible to draw conclusions from day hauls only; these must be supplemented by collections made at night. As stated, the species would appear to be relatively scarce in this region until mid-July, if it were not for the fact that night collections made in June demonstrated 
that they were in reality present here. Southern $(\mathbf{2 y})$ states that off the coast of Ireland collections indicated a maximum in late autumn, especially from August to November; he also says: "Whilst the number of individuals varies with the season of the year, their distribution in space remains very uniform, and there is no seasonal migration." He abstracted the results of the Plankton Investigations of the International Council in the English Area, including the English Channel and the Bristol Channel, and the results agreed with his findings in showing a maximum in the autumn and a minimum in the spring. He states that the breeding season takes place between May and August.

Lebour (17), for the Plymouth Sound region, says that this species begins in the middle of June, and is very common in July and rare in September and October.

MeIntosh (19, p. 17) says, "Autumn seems to be the period in British waters when Tomopterids occur most abundantly, the maximum being in October."

\section{Larva of Pøcilochetus serpens Allen.}

These polychæte larvæ were never abundant. On no occasion were any caught at the surface or in the layers above 12 metres. It would, therefore, seem that Pœcilochætus larvæ normally live in the deeper layers in the daytime.

\section{CHETOGNATHA}

\section{SagitTa BIPUnctata Quoy and Gaimard.}

From April 8th until July 1st the majority of Sagitta were captured from the deeper layers below 20 or 25 metres at the outer station, A. At L4, however, which is closer inshore, on May 19th, June 4th, and July 1st they were considerably higher in the water than at $\mathrm{A}$ on the same dates.

On July 16th and 29th and August 6th, all three foggy days, Sagitta was abundant from 4 or 5 metres downwards and fairly evenly distributed throughout the layers, except on August 6th, when they were apparently concentrated between 10 and $25 \mathrm{~m}$. (Fig. 5).

It was noted that very often the smaller stages were most prevalent in the upper layers, and on this account measurements are being taken of the Sagitta present in this year's (1926) collections.

Seasonal distribution. While present in small numbers in April, May, and June, Sagitta showed an enormous increase in the middle of July; on July 29 th the numbers taken on the 16th were nearly doubled, while these were again doubled by the catch on August 6th. 


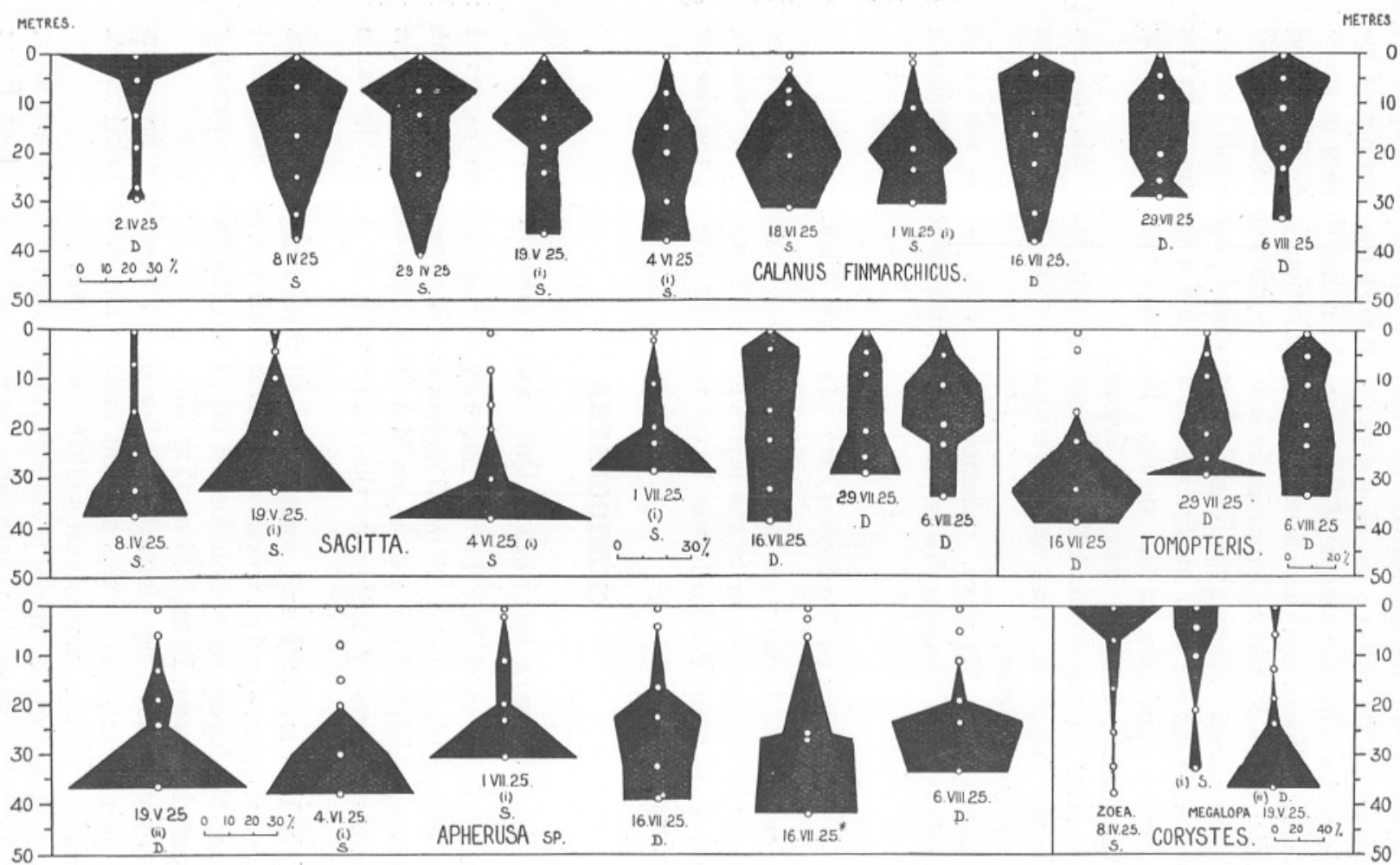

FIG. 5.-The percentage vertical distribution of Calanus finmarchicus, Sagitta bipunctata, Tomopteris helgolandica, Apherusa sp., and Corystes cassivelaunus zoeas and megalopas on the dates given. The white spots and black circles indicate the average depths at which hauls were taken. $\mathrm{S}=$ Sunshine. $\mathrm{D}=$ Dull. Asterisk $(*)=$ closing metre net. Note that the percentage scale for Corystes zoeas and megalopas is half that of the o'her species. (In the case of Calanus, the date 19.v.25 (i.) should read 19.v.25 (ii.).) 


\section{CRUSTACEA.}

\section{BRANCHIOPODA.}

\section{Evadne Nordmanni Lovén.}

Although this species is too small to be normally retained by the ring-trawl, I have one observation on its vertical distribution that was made with the silk closing metre net on July 16th. O_ this day (Table II), although it cannot be said to have been abundant, the largest catch occurred at $25 \cdot 8$ metres. It was absent from the actual surface, but was present in the catch from $2 \cdot 7 \mathrm{~m}$.

\section{Podon Intermedius Lillj.}

This species, again, like Evadne, was only obtained when the silk net was used on July 16th. It was quite abundant on this occasion, and showed a marked maximum at $\mathbf{2 5 \cdot 8}$ metres, though actually it may have been higher in the water because unfortunately there is no haul between $6 \cdot 5$ and $25 \cdot 8 \mathrm{~m}$. (Table II).

\section{COPEPODA.}

\section{Calanus finmarchicus (Gunner).}

In discussing the vertical distribution of this copepod it is desirable to know with which stages of development we are dealing. In the lifehistory of Calanus finmarchicus there are 12 stages - 6 larval nauplius stages, 5 post-larval copepodid stages, and the adult-which have been described by Kröyer, Grobben (10), Lebour (16), and With (28). It is only the copepodid stages that concern us here, the nauplius stages being far too small to be retained by the net used. It has already been noted by previous workers that the younger individuals are at times higher in the water than the older. For instance, Gran (9, p. 64) remarks : “. . . im Sommer sind die Jungen hauptsächlich in den oberen, erwärmten Schichten zu finden, während die älteren oft vereinzelt in der Tiefe umherschwimmen." Damas (4, p. 18) says also: "Verticalement, les stades sont répartis de telle sorte que les individus jeunes prédominent à la surface et les adultes vers la profondeur. Il est probable que les Calanus gagnent vers la profondeur en avançant en âge."

Farran (5, p. 84), for the smaller southern form, gives as an example the following figures showing a preponderance of young forms at the surface and adult forms deeper : the locality was on the west coast of 
Ireland, 30 miles west of Cleggan Co. Galway, and the time of year, May in $1904:-$

$\begin{array}{lrrrrrr}\quad \text { Stages. } & \text { of } & \text { V. } & \text { IV. } & \text { III. } & \text { II. } & \text { I. } \\ \text { Surface } & 2 & 9 & 32 & 27 & 24 & 6 \text { Percentage present. } \\ 35 \text { fathoms } & 73 & 14 & 6 & 3 & 4 & -\end{array}$

In view of these differences in vertical distribution noticed for the various stages of development, I have made observations in order to find out which stages are mostly caught by the ring-trawl.

On July 16th, 1925, horizontal hauls were made at six different depths with a closing net, 1 metre diameter at mouth and silk with a mesh of ca. 40 strands to the inch. The catches consisted of large numbers of Calanus chiefly composed of the last three stages-Adult, V, and IV. Measurements were made of the total length (furcal setæ excluded), and of the thorax only, of 394 individuals. Similar measurements were made of a sample of Calanus collected by the ring-trawl on July 15th, 1924 . The results are given in Table I. It can be seen that whereas the silk net took large quantities of post-larvæ of Stages IV and V, as well as adults (VI), the composition of the ring-trawl catches was made up mostly of adults with only a small proportion of Stage $\mathrm{V}$ and hardly any of Stage IV, the percentage composition being-

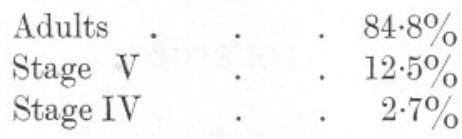

This agrees well with the conclusions of Paulsen (21, p. 11), who says : "These Young fish trawl samples contain only specimens of Stage II* of the Juniores, younger stages pass through the meshes." The young fish trawl is made of the same material - stramin - as the ring-trawl.

As an example I quote some of his figures :-

$\begin{array}{lrrrrrrr} & \text { o } & \text { I. } & \text { II. } & \text { III. } & \text { IV. } & \text { V. } & \text { VI. } \\ \text { Young Fish trawl } & 1 & 89 & 5 & 5 & - & - & - \\ \text { Young Fish tráwl } & - & 77 & 16 & 7 & - & - & - \\ \text { Silk net, Gauze 20 } & - & 13 & 6 & 32 & 16 & 22 & 11 \\ \text { Silk net, Gauze 20 } & - & 44 & 10 & 30 & 16 & - & -\end{array}$

I have also tested five further samples taken on April 9th, 1926, from five different depths, with the following results :-

$\begin{array}{ccc}\text { Adults. } & \text { V. } & \text { IV. } \\ 94 \cdot 8 \% & 5 \cdot 2 \% & - \\ 91 \% & 9 & - \\ 87 \quad, & 13 \% & - \\ 83 \% & 15 \% & 2 \%\end{array}$

* Paulsen's stages are numbered in the reverse order: this, therefore, corresponds to my Stage $V$. 
It can, I think, then, be safely stated that the observations given below on the vertical distribution of Calanus relate almost exclusively to the adult stages, with also a few of the last copepodid stage.

It is, however, unfortunate that it is not possible to say which sex we

\section{TABLE I,}

\begin{tabular}{|c|c|c|c|c|c|c|c|c|c|c|c|c|c|}
\hline \multirow[b]{3}{*}{$\mathrm{Mm}$. } & \multicolumn{6}{|c|}{ Total Length. } & & \multicolumn{6}{|c|}{ Length of Thorax. } \\
\hline & & Silk I & Net. & Rin & $\mathrm{g}$-tra & & & & $\mathrm{k} \mathrm{N}$ & & $\operatorname{Rin}$ & g-tra & \\
\hline & IV. & $\begin{array}{c}\text { Stag } \\
\text { V. }\end{array}$ & e. & IV. & $\begin{array}{l}\text { tage } \\
\text { V. }\end{array}$ & VI. & Mm. & IV.' & $\begin{array}{l}\text { tage } \\
\text { V. }\end{array}$ & & & $\begin{array}{l}\text { ttage. } \\
\text { V. }\end{array}$ & VI. \\
\hline $1 \cdot 76$ & 1 & - & - & - & - & - & $1 \cdot 43$ & 4 & $\because$ & - & - & - & - \\
\hline $1 \cdot 815$ & 3 & - & - & - & - & - & $1 \cdot 485$ & 3 & - & - & - & - & - \\
\hline $1 \cdot 87$ & 3 & - & - & - & - & - & $1 \cdot 54$ & 13 & - & - & - & - & - \\
\hline 1.925 & 8 & - & - & - & - & - & $1 \cdot 595$ & 10 & - & - & - & - & - \\
\hline 1.98 & 11 & - & - & - & - & - & $1 \cdot 65$ & 14 & - & - & 1 & - & - \\
\hline $2 \cdot 035$ & 11 & - & - & 1 & - & - & $1 \cdot 705$ & 10 & 1 & - & 1 & - & - \\
\hline $2 \cdot 09$ & 8 & - & - & - & - & - & $1 \cdot 76$ & 2 & - & - & - & - & - \\
\hline $2 \cdot 145$ & 6 & 1 & - & - & - & - & $1 \cdot 815$ & 2 & 4 & - & - & - & - \\
\hline $2 \cdot 2$ & 6 & 1 & - & 1 & - & - & $1 \cdot 87$ & - & 5 & - & - & - & - \\
\hline $2 \cdot 255$ & - & 1 & - & - & - & - & 1.925 & - & 13 & - & - & - & - \\
\hline $2 \cdot 31$ & 1 & 3 & - & - & - & - & 1.98 & - & 16 & - & 1 & - & - \\
\hline $2 \cdot 365$ & - & 4 & - & 1 & - & - & $2 \cdot 035$ & - & 21 & - & - & - & - \\
\hline $2 \cdot 42$ & - & 7 & - & - & - & - & $2 \cdot 09$ & - & 24 & - & - & 1 & - \\
\hline $2 \cdot 475$ & - & 14 & - & - & - & - & $2 \cdot 145$ & - & $1 \%$ & - & - & 2 & - \\
\hline $2 \cdot 53$ & - & 16 & - & - & - & - & $2 \cdot 2$ & - & 25 & 2 & - & 3 & - \\
\hline $2 \cdot 585$ & - & 23 & - & - & - & - & $2 \cdot 255$ & - & 30 & 3 & - & 3 & - \\
\hline $2 \cdot 64$ & - & 15 & - & - & 1 & - & $2 \cdot 31$ & - & 38 & 5 & - & 3 & - \\
\hline $2 \cdot 695$ & - & 15 & - & - & 1 & - & $2 \cdot 365$ & - & 4 & 15 & - & 1 & - \\
\hline $2 \cdot 75$ & - & 17 & - & - & 4 & - & $2 \cdot 42$ & - & - & 21 & - & 1 & 4 \\
\hline $2 \cdot 805$ & - & 21 & - & - & 1 & - & $2 \cdot 475$ & - & - & 28 & - & - & 5 \\
\hline $2 \cdot 86$ & - & 33 & - & - & 2 & - & $2 \cdot 53$ & - & - & 33 & - & - & 11 \\
\hline $2 \cdot 915$ & - & $2 y$ & 6 & - & 1 & - & $2 \cdot 585$ & - & - & 20 & - & - & 11 \\
\hline $2 \cdot 97$ & - & - & 8 & - & 2 & - & $2 \cdot 64$ & - & - & 12 & - & - & 22 \\
\hline $3 \cdot 025$ & - & - & 20 & - & 2 & 4 & $2 \cdot 695$ & - & - & 2 & - & - & 18 \\
\hline $3 \cdot 08$ & - & - & 20 & - & - & 2 & $2 \cdot 75$ & - & - & - & - & - & 15 \\
\hline $3 \cdot 135$ & - & - & 22 & - & - & 4 & $2 \cdot 805$ & - & - & - & - & - & 6 \\
\hline $3 \cdot 19$ & - & - & 24 & - & - & 9 & $2 \cdot 86$ & - & - & - & - & - & 2 \\
\hline $3 \cdot 245$ & - & - & 15 & - & - & 14 & $2 \cdot 915$ & - & - & - & - & - & 1 \\
\hline $3 \cdot 3$ & - & - & 18 & - & - & 17 & & & & & & & \\
\hline $3 \cdot 355$ & - & - & 4 & - & - & 15 & & & & & & & \\
\hline $3 \cdot 41$ & - & - & 1 & - & - & 15 & & & & & & & \\
\hline $3 \cdot 465$ & - & - & - & - & - & 9 & & & & & & & \\
\hline $3 \cdot 52$ & - & - & - & - & - & 2 & & & & & & & \\
\hline $3 \cdot 575$ & - & - & - & - & - & 2 & & & & & & & \\
\hline $3 \cdot 63$ & - & - & - & - & - & 1 & & & & & & & \\
\hline $3 \cdot 685$ & - & - & - & - & - & 1 & & & & & & & \\
\hline
\end{tabular}

are dealing with. When first undertaken, this research was intended for examination of the depth distributions of the young, pelagic stages of fish, and the plankton was also examined in order to get a general idea of the distribution of some of the other constituents of the animate environment in relation to that of the young fish. It seems, however, 
desirable later that the distribution of each single species be examined in detail.

Nevertheless I can give the vertical distribution of the two sexes for two separate occasions, July 16th, 1925, and April 9th, 1926. The results are given in the following table :-

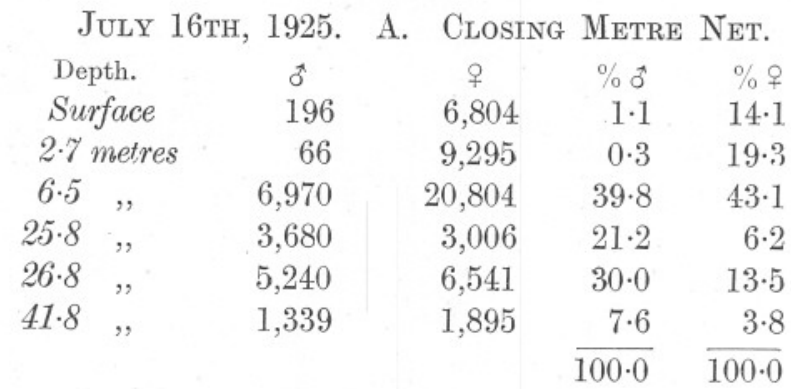

April 9th, 1926. A. Ring-Trawl:

\begin{tabular}{|c|c|c|c|c|c|}
\hline & \multirow{2}{*}{$\begin{array}{r}5 \\
31\end{array}$} & \multirow{2}{*}{$\begin{array}{r}60 \\
812\end{array}$} & \multirow{2}{*}{$\begin{array}{l}0 \cdot 5 \\
3 \cdot 4\end{array}$} & \multirow{2}{*}{$\begin{array}{l}0 \cdot 7 \\
9 \cdot 4\end{array}$} \\
\hline & & & & & \\
\hline \multicolumn{2}{|c|}{$\begin{array}{l}\text { Surface } \\
2 \text { metres }\end{array}$} & 55 & 2,456 & $6 \cdot 1$ & $28 \cdot 0$ \\
\hline 15.5 & , & 438 & 2,738 & $48 \cdot 6$ & $35 \cdot 4$ \\
\hline 22.4 & , & 146 & 958 & $16 \cdot 3$ & $12 \cdot 3$ \\
\hline \multirow[t]{2}{*}{$32 \cdot 4$} & \multirow[t]{2}{*}{, } & \multirow[t]{2}{*}{225} & \multirow{2}{*}{1,047} & $25 \cdot 1$ & $14 \cdot 2$ \\
\hline & & & & $\overline{100 \cdot 0}$ & 100 \\
\hline
\end{tabular}

It can be seen from these figures that on both occasions there was a difference in the vertical distribution of the two sexes, the males exhibiting a greater tendency to avoid the surface layers than the females. This is shown very clearly in Fig. 6. At the same time it is to be noticed that on these two occasions the females so preponderated in numbers over the males that the distribution of the two sexes together did not differ essentially from that of the females alone (Fig. 6). There is therefore a possibility that the distributions shown by my collections may depict that of the females, if on each occasion the males formed as small a proportion of the whole as they did on the two days dealt with above.

Before proceeding with an account of the actual vertical distribution of Calanus in the daytime, in 1925, a further fact of interest shown by Table 1 is worthy of mention; this is the variation in actual size of the adults. We note that while in 1925 the majority lay within the limits of 3.025 and $3.3 \mathrm{~mm}$. in length - with a maximum of 3.4 -in 1924 they were obviously considerably larger, most of them being between $3 \cdot 19$ and $3.465 \mathrm{~mm}$. in length, and one even reaching $3.685 \mathrm{~mm}$. Although it is true that the smaller adults may have passed through the meshes of the 
ring-trawl, thus giving the impression of a larger lower-limit than that shown by the silk net, it is unlikely that the silk net would have failed to catch the largest forms and so produce the opposite effect. It seems, therefore, quite probable that in July, 1924, the Calanus population sampled consisted of larger individuals than that sampled in July, 1925 ; this is also borne out by the fact that the few Stage V specimens retained

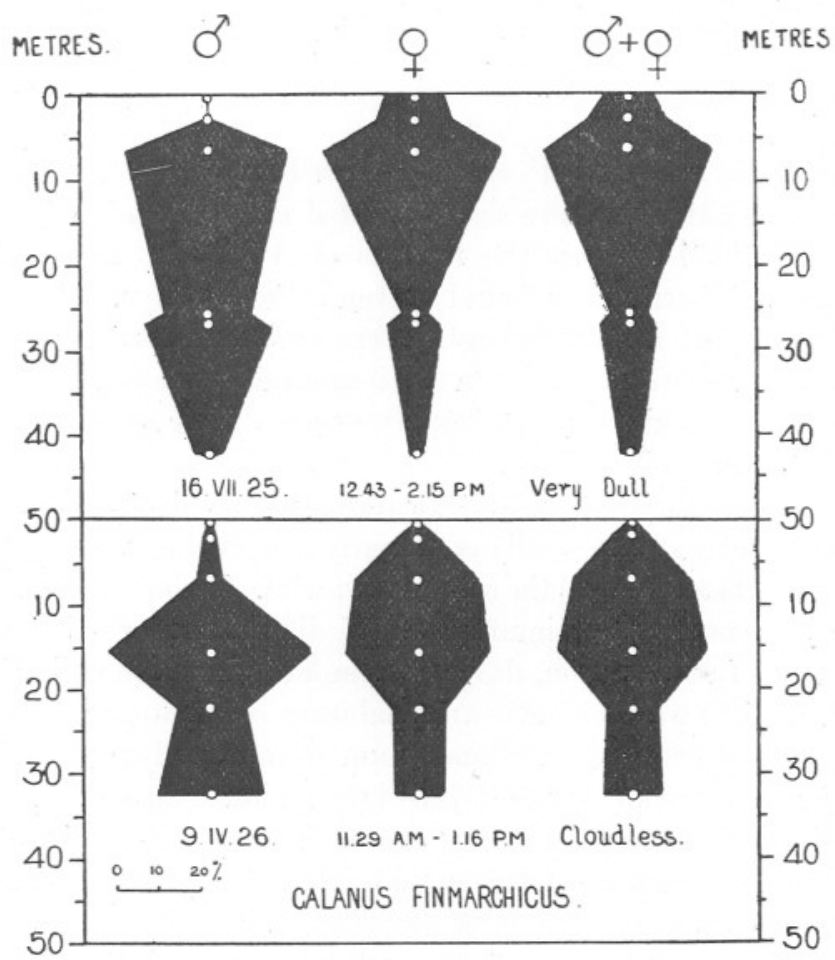

F G. 6.-Percentage vertical distribution of male and female Calanus finmarchicus on Juiy 16th, 1925, and April 9th, 1926, showing-

(i.) The preference of the males for deeper layers than the females.

(ii.) Owing to the preponderance of females over males the combined distribution resembles that of the females.

by the ring-trawl in 1924 were evidently of a larger size than those of the corresponding stage caught in July, 1925.

Such variations in size in the same locality have already been noted by Gran (9,pp. 60 and 64$)$, who says that the sizes for each stage differ according to season, and also that a raising of the temperature accelerates development, but produces smaller forms.

The same has also been noted by Kraeffit $(15$, p. 76$)$ for the copepod Paracalanus parvus. In view of these observations it is interesting to note that, presuming the adult Calanus in question to have been born in the 
spring, those born in 1925 would have developed under conditions at least $1^{\circ} \mathrm{C}$. higher than those born in the spring of 1924, which might explain the smaller size of the adults in 1925. The actual temperatures were :-

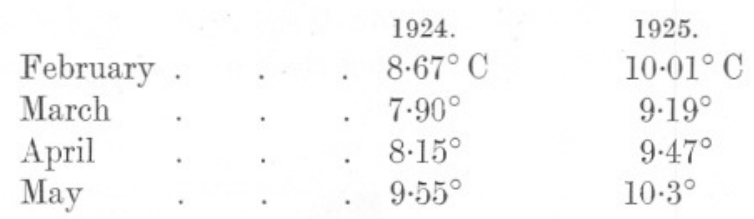

As regards the actual vertical distributions shown by Calanus finmarchicus (which we have seen consisted mostly of adults) during the daytime in 1925, between the months of April and August, in Fig. 5 are given the distributions found on ten different days. The shapes of some of these distribution figures and the apparent descent of the region of maximum abundance between April and mid-June have already been discussed in a previous paper (25) as regards their possible correlation with the intensity of the light.

Calanus exhibits a very wide vertical range in its distribution, occurring fairly abundantly at almost all depths early in April, but gradually avoiding the actual surfacelayers as the season advances. It would, however, appear to have a pronounced optimum level of abundance, which varies from day to day. In this region, during the months in which collections were made in 1925, it was evidently an inhabitant of the upper more brightly illumined layers, the region of maximum abundance lying almost always above the 20-metre level; the depth of the region of maximum abundance showed a marked seasonal change descending from about 5 metres early in April to just below 20 metres in mid-June. Daily changes in this level were also shown, the copepods being higher in the water on dull than on bright days, cf. April 2nd and 8th, and July 1st and 16th.

Seasonal distribution. Calanus was present in all the collections, but showed a very great increase in numbers on July 16th, 29th, and August 6th. Whether these represent individuals transported into this area or whether they were the 1925 brood grown to a sufficient size to be captured by the ring-trawl cannot be said.

Farran (5, p. 85), says that the Channel is not to " be regarded as one of the areas in which the annual presence of vast swarms is normal. Such an area lies, however, immediately off its mouth, and large shoals are frequently carried into the western half of the Channel."

\section{Anomalocera Patersoni Templt.}

The specimens of this copepod dealt with in these collections were probably all adults, the sexes, however, have unfortunately not been 
noted. From Fig. 7 it can be seen that between April 2nd and July 1st Anomalocera showed a decided preference for the actual surface layers above $10 \mathrm{~m}$., at the times at which collections were made. It is noticeable, however, that after July 1st a change appears to have taken place in the way in which they were distributed. On July 16th they were still numerous at the surface, but were. also taken in relatively large numbers even as deep as 22 metres. On July 29th a large catch was made at $29 \mathrm{~m}$., while on. August 6th there were many taken from a depth of $33 \mathrm{~m}$, but on this date the area of maximum abundance appeared to be in the region of $20 \mathrm{~m}$.

With so few observations it is not possible to attempt an explanation of this apparent change in behaviour. Suffice it to say that on these days the weather was very dull; one should also keep in mind the fact that at

METRES.

METRES

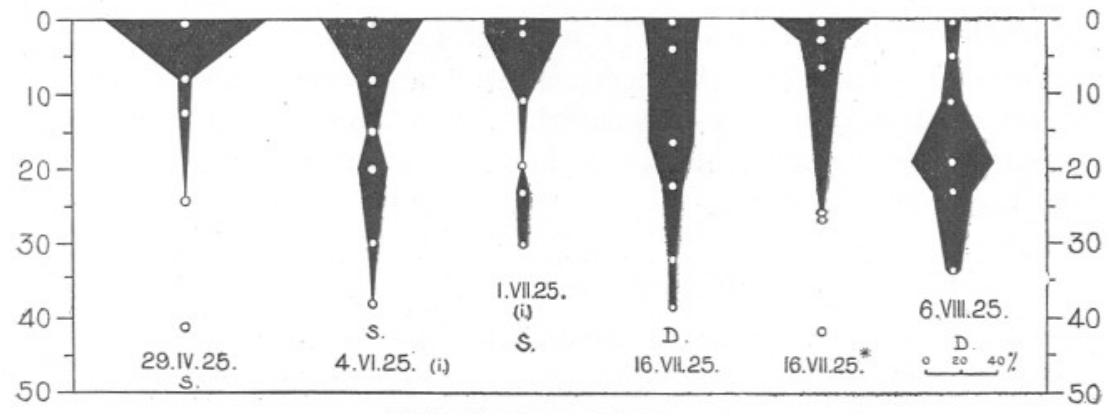

ANOMALOCERA PATERSONI.

FIG. 7.-The percentage vertical distribution of Anomalocera Patersoni on the dates given. The white spots and black circles indicate the average depths at which hauls were taken. $\mathrm{S}=$ Sunshine. $\mathrm{D}=$ Dull. Asterisk $(*)=$ elosing metre net.

this time of year the surface layers are reaching their maximum temperature (25, p. 437).

The collections made on July 16th with the closing metre net do not give quite similar results to those taken with the ring-trawl on the same date: the presence in these samples of many young stages and also the absence of a sample from between the depths of 6 and $25 \mathrm{~m}$. will probably account for this.

From a study of observations by previous workers on the distribution of this species the general conclusion is that it is a surface living form, though it may occur occasionally in deeper layers. Gough's remark (8, p. 336) - " A. Patersoni is usually found at the surface, very rarely descending to 10 metres. In August, however, a few specimens . . . were found in a sample from 110 metres "-may have some significance in view of the fact that it is at the beginning of August that Anomalocera 
occurred deepest in my collections. Farran (6, p. 292) reports the occurrence of this copepod in the 100 -fathom nets in the Biscayan plankton collections; he remarks that they ". . . may possibly have been taken while these nets were being hauled to the surface; but they occurred more often than might have been expected if this were the case."

In 1924 in mid-July I took this species chiefly on the surface on July 15 th, but at all depths down to 30 metres on July 16th; there was a marked massing at 9 and 16 metres at 2.50 to 4.16 a.m. on July 16 th (22, p. 795).

Wolfenden (29, p. 140) remarks: "For long it has been considered that Anomalocera Patersoni was a purely surface species, but the capture of an adult male example in a bottom scraping at 400 fathoms, in perfect condition, shows that it can sometimes descend to considerable depths."

In records given by Savage (26, p. 33) for the North Sea this species. occurred only in surface hauls in July, 1922.

Seasonal distribution. Anomalocera was never very abundant; the largest catch was made on August 6th. The main centre of distribution probably lies very much farther to the westward of this locality, and we only just touch the fringe.

\section{Candacia armata (Boeck.).}

This copepod, mostly adults, showed a decided preference for the layers below a depth of 20 metres in the daytime, as indicated by collections made between April 2nd and July 29th, 1925 ; on August 6th, however,

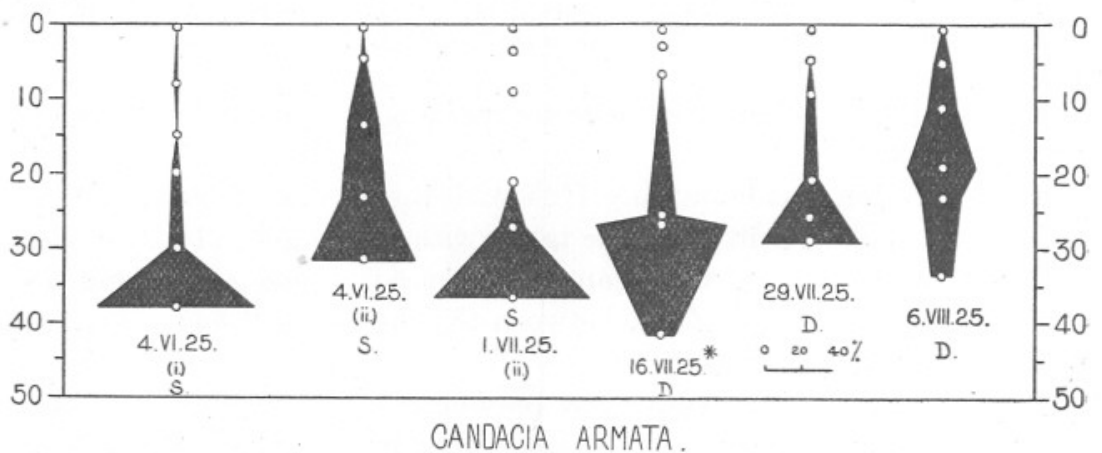

Fig. 8.-The percentage vertical distribution of Candacia armata on the dates given. The white spots and black circles indicate the average depths at which hauls were taken. $\mathrm{S}=$ Sunshine. $\mathrm{D}=$ Dull. Asterisk $\left({ }^{*}\right)=$ elosing metre net.

they occurred in considerable numbers much higher up in the water, the majority occurring at about 20 metres (Fig. 8). 
Lebour (18, p. 403) says that in the winter this copepod, which is an important constituent of the food of Herring, is taken " usually from the lower layers."

Seasonal distribution. This copepod was present throughout the period in which collections were made, but became more abundant at the beginning of June: the largest catch was on August 6th.

\section{Centropages typicus Kröyer.}

This copepod, although occurring occasionally in the ring-trawl catches, has not been counted. On account of its small size the majority most certainly pass through the meshes, and results given by the few that are retained cannot be relied on.

I have, however, in Table II, p. 608, given the results of catches made on July 16th with the silk closing net. From these numbers and a figure previously published (25, p. 425) it can be seen that the majority occurred in the 10-metre region on this date.

\section{Temora LONGICORNIS (Müller).}

As with Centropages catches of Temora obtained by the ring-trawl cannot be relied upon. On July 16th this copepod was also numerous in the closing net collections, and it can be seen from: Table 2 and the previously published figure (25, p. 425) that the majority occurred on this occasion below 25 metres.

Savage (26), working in the North Sea, off the mouth of the Tyne, found in July that in the daytime the majority of this species were in the bottom layers, and he has drawn charts showing the distribution of Temora over a given area that bring this out in a very striking manner.

\section{IsIAS CLAVIPES Boeck.}

This species only occurred in the catches made with the silk closing net on July 16th, and then they were present only in small numbers. The figures obtained by sampling the catches showed that none occurred at the surface or at 2.7 metres; at $6.5 \mathrm{~m}$. there were 40 specimens; at $25.8 \mathrm{~m} ., 40$; at $26 \cdot 8 \mathrm{~m}$. and at $41.8 \mathrm{~m}$., 20 .

\section{Metridia Lucens Boeck.}

This copepod only occurred occasionally in the ring-trawl; it is possible that it is just small enough for the majority to pass through the meshes of the ring-trawl ; this locality is also probably far from the main area of 
its distribution which lies in deeper water farther to the west. On the three dates on which any were found in the collections, April 22nd, June 17 th, and August 6th, none were taken from above 15 metres. It was also present in the silk metre net collections on July 16th, when it occurred only in the three deeper hauls.

\section{Caligus rapax Milne Edwardes.}

Free-swimming males and females of this species occurred in small numbers on each day on which collections were made. They were always most numerous below a depth of 18 to 20 metres. In fact, between April 2nd and June 4th none were captured in the layers above this depth.

Seasonal distribution. Caligus rapax showed a decided increase in abundance in the middle of June and remained abundant for the rest of the period, during which observations were made; the largest catches were made on August 6th.

\section{MYSIDACEA.}

Mysids live in the daytime generally either on or very close to the bottom, and it is natural that they were very rare in my collections. The largest catches occurred on June 4th, when 41 were taken at 30 metres and 125 at 38 .

It is, however, of interest to record the presence of extremely young mysids in the plankton, on July 16th, in the catches of the metre net. It can be seen in Table II that while of the adults 1 was caught at $26.8 \mathrm{~m}$. and 21 at $41.8 \mathrm{~m}$., the very young stages were quite numerous at $25 \cdot 8$ and $26.8 \mathrm{~m}$., although the majority were at $41.75 \mathrm{~m}$.

\section{EUPHAUSIACEA.}

\section{Nyctiphanes Couchil (Bell).}

Both adults and young (including the later Cyrtopia stages) kept apparently nearly always to the deeper layers below 20 metres in the daytime. On July 16th collections made by the closing metre net gave a definite indication that the Furcilia stages were abundant higher in the water-up to the 6-metre level - than the adults, although they were also abundant in the deeper layers, the numbers being as follows :-

\begin{tabular}{|c|c|c|c|c|c|c|}
\hline & $\begin{array}{c}\text { Surface. } \\
. \quad-\end{array}$ & $\begin{array}{c}2 \cdot 7 \mathrm{~m} . \\
-\end{array}$ & $\begin{array}{c}6 \cdot 5 \mathrm{~m} . \\
100\end{array}$ & $\begin{array}{c}25 \cdot 8 \mathrm{~m} . \\
140\end{array}$ & $\begin{array}{c}26 \cdot 8 \mathrm{~m} . \\
40\end{array}$ & $\begin{array}{c}41 \cdot 8 \mathrm{~m} \\
100\end{array}$ \\
\hline dults & - & - & - & 4 & 25 & 63 \\
\hline
\end{tabular}


Lebour (18, p. 404) states that " the adults and older larvæ all appear to live very near the bottom in the daytime, . . . although the young larvæ seem to keep near the surface." Also (p. 411), " the younger larval stages, especially the Calyptopis, were nearly always at the surface or midwater, the post-larvæ near the bottom. . . ."

A curious exception to the apparently normal behaviour of adult Nyctiphanes occurred on June 4th, when besides being abundant below 25 metres they were very numerous right at the surface during bright sunshine.

\section{AMPHIPODA.}

\section{ApHerusa sp.}

There are possibly several species of Apherusa included in the collections. On account of the labour that would be involved in carrying out the identifications they are here dealt with together. Examination of a certain number has shown that besides Apherusa clevei G. O. Sars, there were also present many $A$. ovalipes Norman and Scott; in fact, 'the impression gained was that of the two $A$. ovalipes was the commoner.

These amphipods on almost all occasions were absent from the surface, and did not become abundant until the 20 -metre level was reached (Fig. 5). On two occasions (19.v.25 (i.) and 1.vii.25 (ii.)) they occurred at the surface : I am inclined to feel, however, that this may have been accidental, as these amphipods have a habit of sticking very strongly to the material of the net, and it may well be that they were left over on the surface of the net from the previous deep hauls.

\section{HYPERIID sp.}

Hyperiid amphipods were very rare in the collections, and always occurred below 19 or 20 metres when present.

\section{DECAPODA.}

\section{DECAPOD LARVA.}

In the period during which these observations were made the decapod larvæ form a very important constituent of the catches made by the ringtrawl. The identification of many of the larval decapods is a matter of considerable difficulty, and consequently I have assigned to the actual species only those that are at once distinguishable even with the naked eye, the remainder being placed together under the families or groups to which they belong. The following scheme shows the result of the final sorting :- 


\section{Macrura.}

Palæmonidæ. Leander serratus.

L. squilla.

Grouped together as

Leander sp.

Pandalidæ.

Hippolytidæ.

Pandalus montagui.

Pandalina brevirostris.

Processidæ.

Spirontocaris Cranchi.

Processa canaliculata.

Grouped under the heading: Pandalid larvæ (the larvæ of Spirontocaris were very scarce).

Alpheidæ.

Crangonidæ.

Alpheus ruber.

Identified.

Crangon allmanni.

C. vulgaris.

Cheraphilus nanus.

C. trispinosus.

Pontophilus spinosus. Identified.

Nephropsidæ.

Homarus vulgaris.

Identified.

Palinuridæ.

Palinurus vulgaris.

Identified.

Galatheidæ.

$\left.\begin{array}{l}\text { Galathea dispersa. } \\ \text { G. intermedia. } \\ \text { G. squamifera. } \\ \text { G. strigosa. }\end{array}\right\}$

Grouped under the headings: Galatheid larvæ and Galatheid postlarvæ.

Callianassidæ. Upogebia stellata. $U$. deltura.

Grouped under the headings: Upogebia larvæ and Upogebia post-larvæ.

Callianassa subterranea. Identified.

Axiidæ. Axius styrhinchus. Identified.

Paguridæ. Eupagurus bernhardus.

E. cuanensis.

E. Prideauxi.

E. sculptimanus.

Diogenes varians.

Anapagurus lavis.

Grouped under the headings : Pagurid larvæ and Pagurid Glaucothoë. 


\section{BRACHYURA.}

Porcellanidæ. Porcellana longicornis. P. platycheles.

Leucosiidæ.

Corystidæ.

\section{Ebalia Cranchi. \\ E. tuberosa. \\ E. tumefacta.}

Corystes cassivelaunus.
Grouped under the headings : Porcellana zoea and Porcellana post-larvæ.

Grouped under the headings: Ebalia zoea and Ebalia megalopa.

Identified-zoea and megalopa.

All remaining brachyura (crabs) were separated into zoeas and megalopas and grouped together : by far the most abundant are probably Portunus spp., together with Cancer pagurus, Carcinus manas, Inachidæ and Maiidæ.

The various decapod larvæ show marked differences in their types of vertical distribution, the details of which are given in the ensuing pages.

For instance, while Leander sp. larvæ were evenly distributed from the surface downwards with a slight preference for the surface layers, Upogebia larvæ had their region of maximum abundance a few metres beneath the surface, Porcellana zoeas were slightly deeper, Galatheid and Pandalid larvæ (including the larvæ of Processa canaliculata) deeper still, then Pagurid larvæ, and deepest of all, Crangonid larvæ and Pontophilus spinosus larvæ. Of Brachyuran larvæ many zoeas frequented the surface layers as well as greater depths, notably Corystes cassivelaunus and probably Portunus sp. : Ebalia sp. zoea, on the other hand, when identified, were much deeper in the water.

Savage, in the North Sea, in July, 1922, as a result of one serial collection had indications of differences in the behaviour of decapod larvæ. On p. 13 (26) he remarks : "It was noted above that Portunus spp. were the only decapod larvæ that were more abundant at the surface than in other layers, and the comparative absence of these species from this station left the surface waters practically devoid of decapod larvæ. Galathea intermedia was the most abundant form, and it had a big maximum at 25 fathoms, where 50 per cent of its total number was taken, the majority of the remainder were below this depth. Pandalus brevirostris and Eupagurus bernhardus were almost wholly in the bottom hauls (35-45 fathoms) particularly the latter. Crangon allmanni was only found between 25 and 35 fathoms."

In this order of their depth distribution the decapod larvæ follow fairly closely my own results. Savage's results differ in the position of Crangon allmanni, but possibly the actual numbers caught were rather low to draw conclusions from. 


\section{LEANDER sp. LARVÆ.}

It is probable that these larvæ consist mostly of $L$. serratus and $L$. squilla. Gurney says (13, p. 101): "Owing to the difference in the breeding period, any Leander larvæ found off the British Coasts from December to nearly the end of June may confidently be assigned to L. serratus" ; and (ibid., p. 105), "From then onwards the larvæ probably comprise both L. serratus and L. squilla, whose larvæ probably appear in the plankton in July."

The stages of development dealt with here are mostly late ones: the actual percentages of different stages in the collections are :-

$\begin{array}{cccccc}\text { Stage. } & \text { I. } & \text { II. } & \text { III. } & \text { IV. } & \text { V. } \\ \text { Percentage } & \text { I } & 3 \cdot 5 & 15 \cdot 5 & 26 & 54\end{array}$

No post-larval stages were met with.

In a previous paper (22, p. 799) I have given the vertical distribution for these decapod larvæ for July 15th and 16th, 1924, showing that on that occasion they were more abundant in the surface layers. In 1925 they were also comparatively numerous in the upper layers from the surface down to about 10 metres: at the same time they occurred also in the deeper layers, so that their vertical distribution would appear to have been somewhat indiscriminate. Between the surface and $10 \mathrm{~m}$. in the whole collections 63 individuals occurred out of 35 hauls in those layers : between 10 and $20 \mathrm{~m}$. there were 30 specimens out of 14 hauls : between 20 and $30 \mathrm{~m} .33$ out of 19 hauls, and between 30 and $40 \mathrm{~m}$. 14 individuals out of 11 hauls. So that the average numbers of specimens per haul in the different layers were :-

$$
\begin{aligned}
& \text { Surface to } 10 \mathrm{~m} \text {. } \quad \text {. } \quad \text {. } \quad \text {. } 1.8 \\
& 10-20 \mathrm{~m} . \quad \text {. . . . } 2 \cdot 14 \\
& 20-30 \mathrm{~m} . \quad \text {. } \quad . \quad . \quad 1.73 \\
& 30-40 \mathrm{~m} . \quad \text {. } \quad . \quad . \quad 1 \cdot 27
\end{aligned}
$$

This points to a fairly even distribution with a tendency for greater abundance between 10 and $20 \mathrm{~m}$. : the numbers are, however, really too low to be significant.

Seasonal distribution. These larvæ were present in fairly equal numbers from mid-April until the beginning of August, when collecting ceased.

\section{PANDALID LARV $\pi$.}

Included amongst these larvæ are mostly Pandalus Montagui* Leach, Pandalina brevirostris (Rathke), and Processa canaliculata Leach. Larvæ

\footnotetext{
* It is here necessary to point out an error that I made in my first paper (22, p. 800 ), where I called this species by mistake $P$. borealis, a northern species that has never been recorded in this locality.
} 
of Spirontocaris Cranchi (Leach) were also occasionally present, but only in extremely small numbers.

Practically all the stages captured by the ring-trawl were of stages 4 and 5 or older.

Fig. 9 shows that throughout the months April to August in 1925 these larvæ avoided the surface and upper layers, only becoming abundant below the 15-metre level, in the daytime. It was noted that on April 2nd only Processa larvæ were present. Gurney (12, p. 263) criticises the fact that Processa is usually placed so near to the Crangonidæ; his argument being that the larval characters differ so markedly from those of Crangonid larvæ. It is interesting therefore to note that in their habits also the larvæ of Processa differ from Crangonid larvæ. While Processa larvæ on April 2nd were present in the water layers from about 15 metres downwards, Crangonid larvæ, as always, were only abundant below 25 metres : in this all Crangonid larvæ, including those of Pontophilus spinosus, appear to be very consistent (see Fig. 9).

Seasonal distribution. These Pandalid larvæ were very numerous in the plankton from the end of April to the end of July. In April they were less numerous; and it has been mentioned that all those examined on April 2nd, and also most of those in the catches of April 22nd, proved to be Processa canaliculata. After this date the samples were not sorted.

\section{Larve of Alpheus ruber Milne-Edwards.}

These larvæ were only taken in the daytime on July 29th and August 6th, 1925, when their numbers were:-

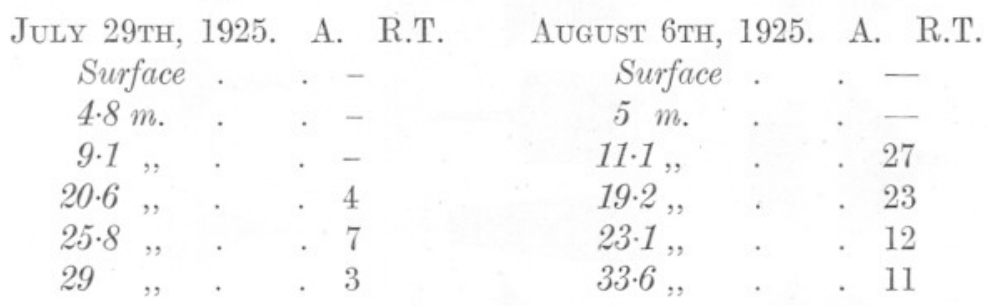

From this it will be seen that they avoided the uppermost layer above about 10 metres : both these days were, however, very dull and foggy.

\section{Crangonid LaRvæ.}

Larval Crangonids, including probably most of the local species, with the exception of Pontophilus spinosus, and with Crangon Allmanni as the most common, showed a consistent preference for the deeper layers below 20 and 25 metres (Fig. 9). In July, 1924, the indications were also 
METRES.
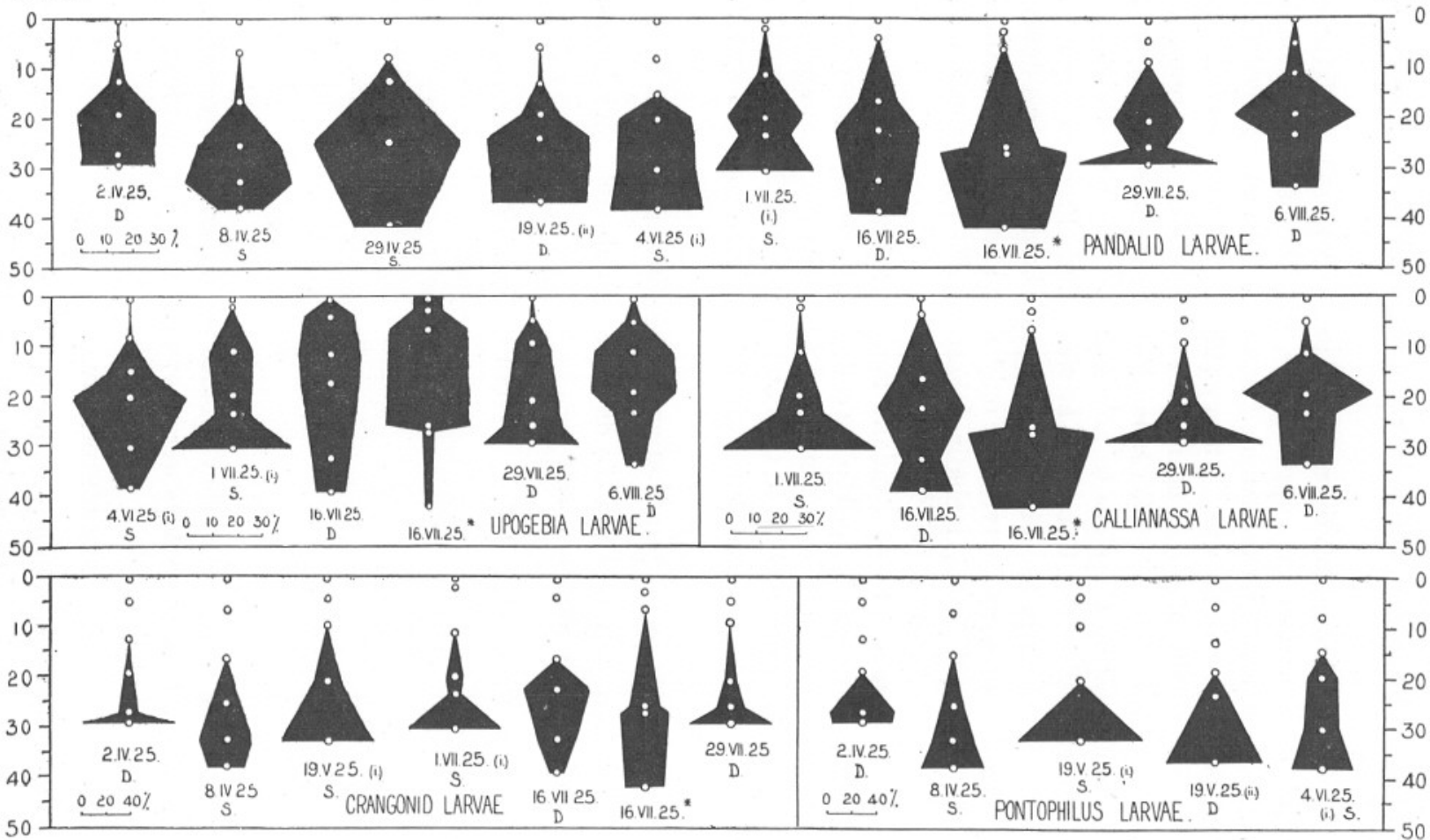

FIG. 9.-The percentage vertical distribution of Pandalid larvæ; Upogebia sp. larvæ, Callianassa subterranea larvæ; Crangonid larvæ and Pontophilus spinosus larvæ, on the dates given. The white spots and black circles indicate the average depths at which hauls were taken. $\mathrm{S}=$ Sunshine. $\mathrm{D}=$ Dull. Asterisk $\left({ }^{*}\right)=$ closing metre net. Note that the percentage scale for Crangonid and Pontophilus larvæ is half that of the other species. 
that they were deep living forms (22, p. 801). Not a single specimen was caught above 12 metres in 1925, and only six above 19 metres, out of a total of 1909 caught.

Seasonal distribution. Crangonid larvæ were present in the catches in greater or less numbers throughout the period of collecting.

\section{LARve of Pontophilus spinosus Leach.}

Like other Crangonid larvæ, Pontophilus exhibited a decided preference for the layers below 20 or 25 metres, being practically entirely absent above 20 metres (Fig. 9). All stages of development were represented in the catches, though the later stages were most abundant.

Seasonal distribution. Pontophilus larvæ were most numerous between April 2nd and June 4th, after which time they were rarely caught.

\section{Larve of Homarus vulgaris Milne-Edwards.}

Only 6 of these larvæ were captured : 1 on May 19th, at the surface ; 1 on July 1st, at $21.3 \mathrm{~m}$. ; 2 on July 16th, at the surface; and 2 on July 29 th, at 29 metres.

\section{Phyllosoma larva of Palinurus vulgaris Latreille.}

These Phyllosoma larvæ probably mostly belonged to Palinurus vulgaris, though there is a slight possibility that one or two Scyllarus arcturus may have been present, as the adult of that species is occasionally, though somewhat rarely, taken in this locality. These larvæ were most common below 16 metres and very rarely occurred above 10 metres. The largest catch, of 75 specimens, was made at $36.7 \mathrm{~m}$. on July 1st. There are indications that the region of maximum abundance may normally have lain deeper than the net fished on most occasions, because on June 17th, 18 th, and 19th in the daytime the total catches were 6,5 , and 44 , while on the two nights between these days they were 102 and 196 .

Cunningham (3, p. 147) says : " . . . some hundreds may be taken in about an hour in the neighbourhood of the Eddystone in July, with a net whose meshes are about $2 \mathrm{~mm}$. in diameter, and whose mouth is 8 feet by 6 feet area. On the two occasions on which I obtained the larvæ, I captured them only when towing the net at the surface, not when it was sunk to some depth." These results are opposed to mine, but it may be that the catches were made much nearer the Eddystone rocks, where upwelling currents might upset the normal distribution of the plankton in more quiet waters. The exact positions were not given, but were " a little to the north of the Eddystone" and "to the south of the Eddystone." 
Seasonal distribution. It is evident that the larvæ were present throughout the months April to August; I have noted, however, that up till the end of June they were all small early stages ; on July 1st, 2 " large " specimens were caught ; on July 16th, 1 " large "; July 29th, 10 " large "; and August 4th, 4 "large." From this it would appear that metamorphosis into the "Puerulus" stage would occur mostly after June in July and August, my "large" stages being stages 7, 8 , and 9 of Bouvier. This agrees with Bouvier (1, p. 191), who says that the last stage but one (avant-dernier stade) is very common at the end of July and during the month of August.

\section{Galatheid LaRve.}

Fig. 10 shows the vertical distribution for Galatheid larvæ on most of the days when collections were made between April and August. They usually showed a sudden increase in abundance between about 15 and 20 metres, and occasionally deeper. In their distribution then they were very similar to the Pandalid larvæ. On April 2nd they were abundant at the surface, and then the numbers decreased until below 20 metres, when they again became abundant. It is curious that on this day many forms which usually live deeper down were present at the surface.

Seasonal distribution. Although occurring on all days on which collections were made, Galatheid larvæ were most numerous on May 19th and June 4th.

\section{Galatheid post-Larvæ.}

These post-larvæ were never very abundant, but when they did occur in fair numbers, e.g. June 4th, they were most numerous below 30 metres. Probably the majority live still deeper in the layers close to the bottom ; this has been indicated by the increase in numbers caught at night (22, p. 803). It is possible that included among these may be a few postlarvæ of Porcellana before July 1st, after which date the presence of Porcellana post-larvæ was noted.

\section{UPOGEBIA spp. LARVA.}

Larval forms of Upogebia, including probably both $U$. deltura Leach, and $U$. stellata (Montagu), showed a tendency to be distributed higher in the water than most species of decapod larvæ. On. June 4th they became abundant at a depth of about 15 metres below the surface at position $A$, and just below 10 metres at L4. On the other days from July 1st to August 6th they only avoided the actual surface layers, and were found abundantly at 10 or even 5 metres (Fig. 9). 
Seasonal distribution. Upogebia larvæ were practically absent from the catches until June 4th; at this date it was noticed that they were all in the early stages of development without the possession of uropods. By June 17th later stages, in which uropods were present, were caught. Another batch of young stages occurred on August 6th. All larvæ became very much more numerous by July 16th, and the numbers were still increasing on August 6th.

\section{UPOGEBIA spp. POST-LARVA.}

These post-larvæ were very scarce in the collections; when present they were nearly always below 20 metres. Probably this stage is almost bottom living. The post-larvæ of both $U$. deltura and $U$. stellata were noticed.

\section{Larve of Callianassa subterranea Leach.}

Larvæ of this decapod were most numerous below 20 metres, except on August 6th, when they were slightly higher in the water (Fig. 9). Like the zoeas of Porcellana, on July 1st at L4, Callianassa larvæ were extremely abundant at $36 \cdot 7 \mathrm{~m}$., while at all depths above they were relatively scarce.

Seasonal distribution. Callianassa larvæ did not appear at all in the collections until June 17 th. The numbers were very much increased on July 16 th and 29 th.

\section{Larve of Axius styrhinchus Leach.}

These larvæ were only caught on three days in the daytime. On June 17 th one at $29.8 \mathrm{~m}$. ; on July 1st at L4 one was taken at $27 \cdot 1 \mathrm{~m}$. and 3 at $36.7 \mathrm{~m}$.: on August 6 th two specimens were caught at each of the following three depths respectively, $19 \cdot 2,23 \cdot 1$, and $33 \cdot 6$ metres. This slight evidence then points to their preference for the layers below a depth of 15 metres.

\section{PAgURID LARVA.}

Fig. 10 shows that these larvæ lived generally deep down, below the 20-metre level, and from the shapes of most of the distribution diagrams it would appear that the upper portion only of their vertical distribution region was sampled. They thus lie slightly deeper in the water than the Galatheid larvæ, whose numbers can be seen from Fig. 10 mostly to be decreasing in the deepest hauls.

Seasonal distribution. Pagurid larvæ were present in all the collections, the largest catch occurring on May 19th. 


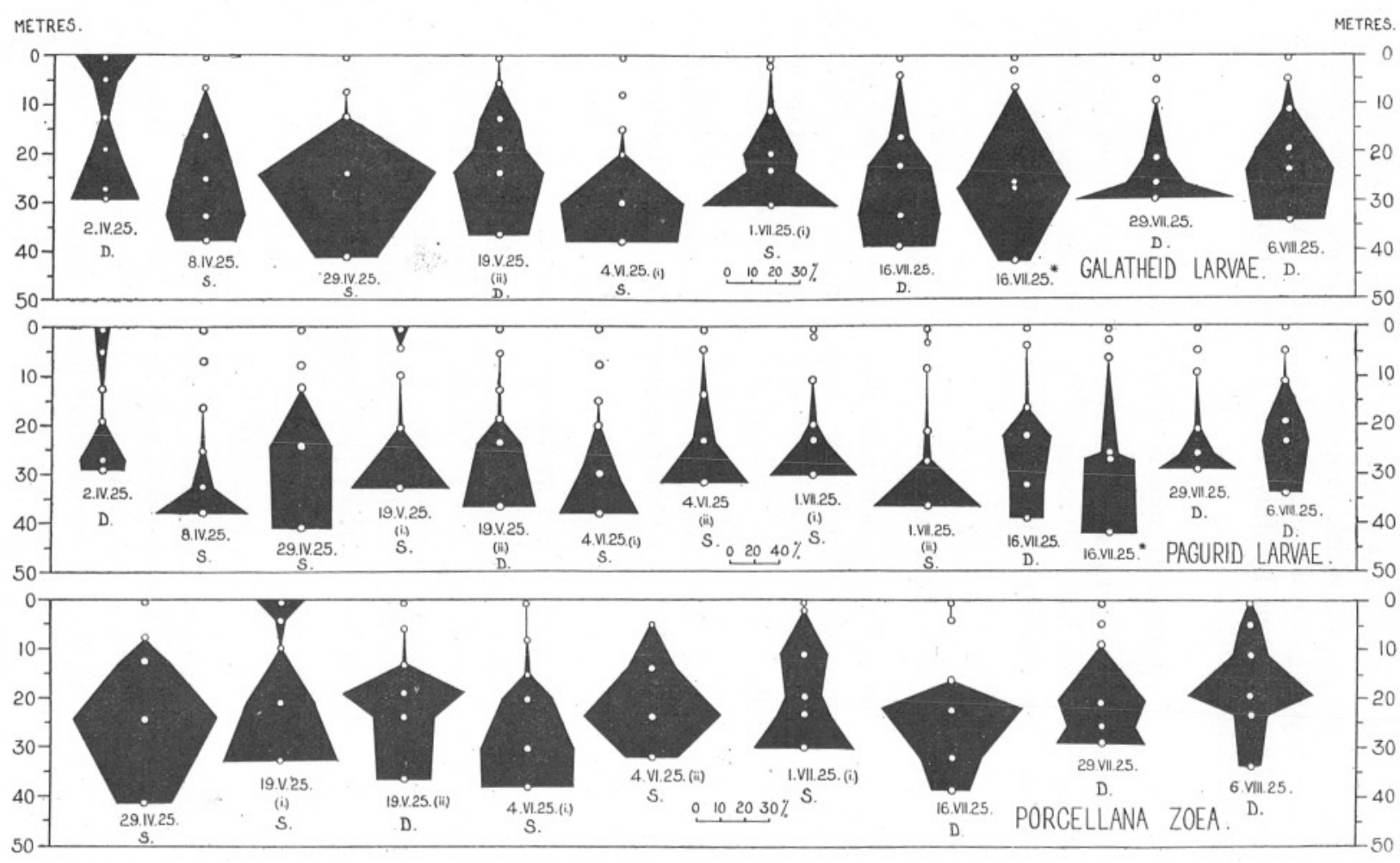

FIG. 10.-The percentage vertical distribution of Galatheid larvæ, Pagurid larvæ, and Porcellana sp. zoeas, on the dates given. The white spots and black circles indicate the average depths at which hauls were taken. $\mathrm{S}=$ Sunshine. $\mathrm{D}=\mathrm{Dull}$. Asterisk $\left({ }^{*}\right)=$ closing metre net. Note that the percentage scale for Pagurid larvæ is half that of the other two species. 


\section{Glaucothö̈ larve of Pagurids.}

These post-larval stages of the hermit crabs were not very numerous, when they did occur, however, it was nearly always below 22 metres. The largest catches were on May 19th, at L4, when 12 were taken at 23.7 metres and 62 at $36.5 \mathrm{~m}$.

It seems probable, however, that generally this stage lives actually on, or very near to, the bottom in the daytime, as the numbers in the deeper layers always increase at night, apparently indicating that the animals have come from still deeper levels ; this occurred in July, 1924 (22, p. 805), and also again in June, 1925, but the results on this occasion are not yet published.

\section{Porcellana spp. zoea.}

The zoeas of Porcellana, probably $P$. platycheles (Pennant) and $P$. longicornis (Linnæus), were very abundant at most of the stations. In Fig. 10 it can be seen that in the majority of cases they show an increase in numbers below 15 metres, being comparatively scarce in the upper layers.

It is noticeable that on May 19th at Station A there were large quantities at the surface itself; in this they agree with many other of the plankton organisms on this occasion, the surface catch being characterised by a large mass of Corystes zoeas. Worthy of note also is the catch made at $36.7 \mathrm{~m}$. on July 1st at L4, in which the enormous number of 62,820 Porcellana zoeas were present, while at all depths above this they were comparatively scarce.

Seasonal distribution. Porcellana zoeas were absent in the catches on April 2nd and April 8th, but had become very numerous by May 19th, after which date they remained abundant throughout the period of collecting.

\section{Porcellana spp. Post-Larve.}

Post-larval stages of Porcellana from July 1st onwards always occurred below the 20-metre level. It is possible that like the Galatheid postlarvæ these may be more numerous in the water layers adjacent to the bottom. Before July lst there may possibly have been some of these postlarvæ included with those of Galathea, as it is from this date only that I started to separate the two post-larvæ; in any case they cannot have been numerous as the numbers given for the Galatheid post-larvæ are low.

\section{Crab Zoeas.}

All the Crab zoeas are here treated together except for the later stages of Corystes cassivelaunus, and, after June 19th, the zoeas of Ebalia sp., which are dealt with separately below. It can, however, be fairly safely 


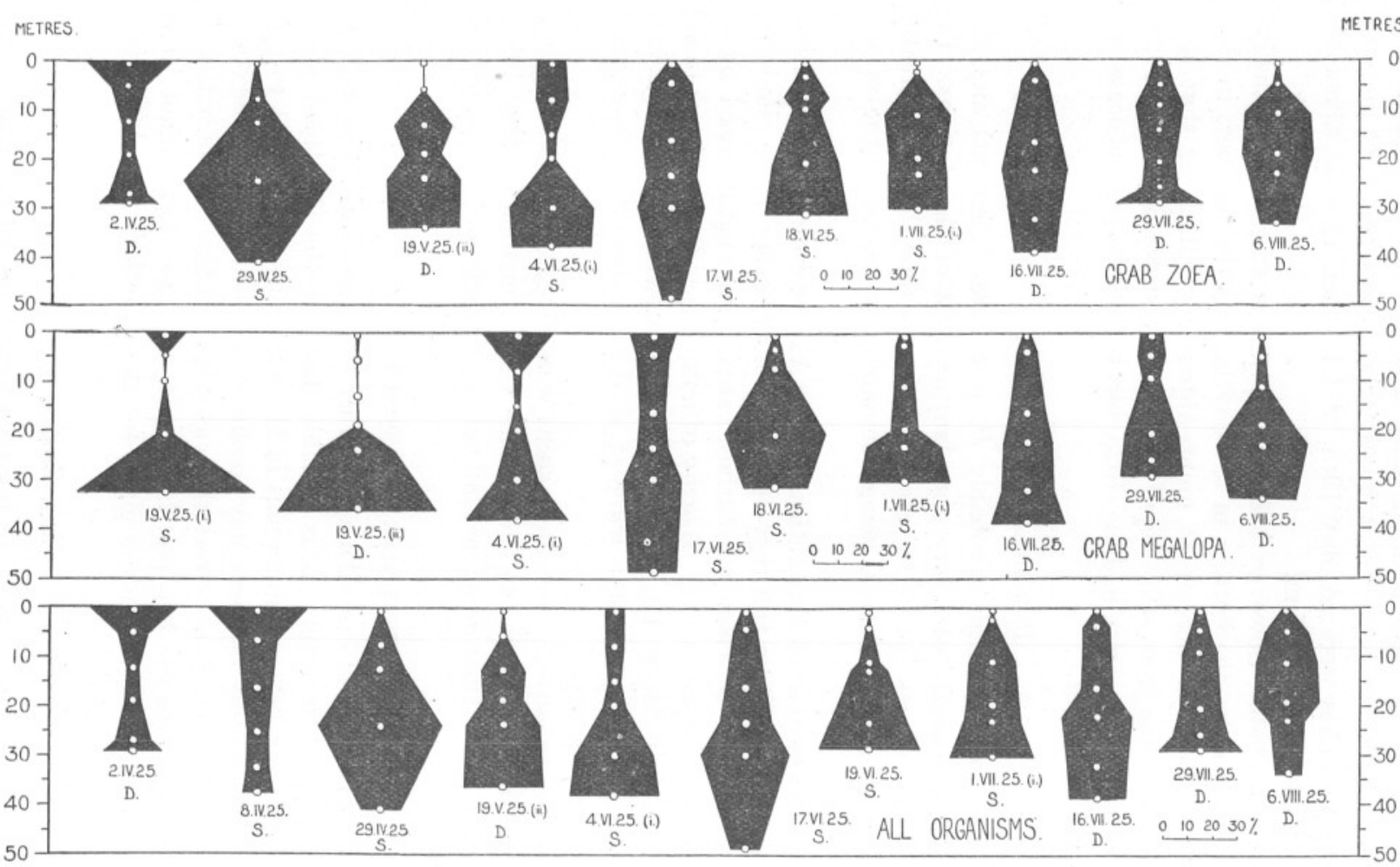

Fig. 11. - The percentage vertical distribution of Crab zoeas, Crab megalopas, and all organisms taken by the ring-trawl on the dates given. The white spots and black circles indicate the average depths at which hauls were taken. S=Sunshine. $\mathrm{D}=\mathrm{Dull}$. 
said that the majority will be those of Portunus spp., these being by far the commonest in this locality. It is likely that different species of crabs will exhibit different behaviour, and, indeed, such is indicated by the zoeas of Ebalia sp., and in the 1926 material there are indications that Hyas sp. prefer the deeper layers: there is a strong possibility, however, that the Portunus spp. zoeas will on almost all occasions be present in such an overwhelming majority that the presence of other species may not significantly upset the true picture of their vertical distribution: I am not in a position to state this for certain. Of the Portunus spp. present near Plymouth, $P$. depurator (Linn.) is the most prevalent.

Fig. 11 shows the percentage vertical distribution of Crab zoeas throughout the period of collecting. It will be noticed that while, usually, they avoided the actual surface layers, they were frequently numerous right up to within 5 metres of the surface. It is interesting to find that Savage (26, p. 10) noted in the North Sea in July that "Portunus spp. (principally $P$. depurator and $P$. holsatus) . . . differed from the Macrura and the Anomura in that the greatest numbers were found in the surface hauls."

Seasonal distribution. Crab zoeas, although numerous in all collections, were by far the most abundant on May 19th. The very large catch of 87,060 at position $\mathrm{A}$ in the haul at $32.6 \mathrm{~m}$. is noteworthy.

\section{Crab Megalopas.}

These include all species except Corystes cassivelaunus and, after July 16th, Ebalia sp. From a study of Fig. 11 it can be seen that there is a tendency for Crab megalopas to be slightly deeper in the water than the zoeas. On the other hand, there were occasions when they were relatively numerous actually at the surface itself.

Seasonal distribution. These megalopa stages of crabs were most abundant on May 19th and June 4th.

\section{Ebalia sp. zoea.}

Until June 19th these zoeas were not separated from the main mass of Crab zoeas. On and after this date they were identified, and it was noticeable that they preferred the deeper layers, being absent always above 20 metres. On July 16th many of these zoeas, which are very small, were retained in the catches of the silk metre net, when the largest catch occurred at $41.75 \mathrm{~m}$. (see Table II).

\section{Ebalia sp. megalopas.}

These were only identified from the remaining Crab megalopas on and after July 16th, when they occurred only in small numbers, generally in the deeper layers. 


\section{Zoea of Corystes cassivelaunus (Pennant).}

Corystes zoeas, mostly stages 3 and 4 , on the two occasions on which they were taken appeared to show a preference for the surface layers. On April 8th a very thick shoal was encountered, and Fig. 5, p. 578, shows that the majority were located right at the surface. This swarm was very visible from the deck of the ship, and we were well in the middle of it when the first three hauls at the surface, 6.9 and 16.5 metres were made. No swarm was, however, visible, the ship having moved out of the area, when the deeper hauls at $25 \cdot 3,32 \cdot 5$, and $37 \cdot 8$ metres were made, so that it might be said that there was not evidence that in the centre of the swarm the zoeas were not just as numerous in the deeper layers as at the surface ; the results for the upper three depths, however, when we were well in the shoal, point to a marked decrease in numbers from the surface downwards.

Seasonal distribution. After May 19th no Corystes zoeas were seen : it is evident that the majority of later stage zoeas were to be found in early April. Gurney, in 1902, observed the same. He says (11): "Occurring first on February 21st, the larvæ were obtained in small numbers fairly regularly from that time onwards. Advanced stages occurred first on March 15th, and in considerable numbers. The townet collections of April 14th, taken in the West Channel, were remarkable for the extraordinary abundance of the zoea stages of Corystes. They abounded on that date to the almost complete exclusion of all other zoeas, nearly all the specimens being at an advanced stage of development. Since April 14th the zoeas have continued to occur, but very few have been found in the early stages.":

\section{Megalopa of Corystes cassivelaunus (Pennant).}

On April 8th one megalopa was taken at the surface, and on April 22nd one at 51.4 metres. On May 19th Corystes megalopas were very abundant: on this day two stations were made, one at L4 and the other at A. It is interesting that at $\mathrm{A}$, where they were very numerous, they were mostly located at the surface, while at L4, where their numbers were considerably smaller, the majority were in the deeper layers (Fig. 5, p. 578). The actual numbers were :-

$\begin{array}{ccccccl}\text { 19.v.25 (i.) } & & \text { Surface. } & 4.3 & 9 \cdot 9 & 20 \cdot 8 & 32 \cdot 6 \text { metres. } \\ \text { A. } & 4050 & 3970 & 2110 & 153 & 1214 \\ \text { 19.v.25 (ii.) } & \text { Surface. } & 5 \cdot 6 & 12.9 & 18.9 & 23.7 & 36 \cdot 5 \text { metres. } \\ \text { L4. } & 34 & 8 & 5 & 25 & 59 & 430\end{array}$


It was noted that at A, where the great shoal of megalopas was located, the diatom Rhizosolenia was extremely abundant, whereas at L4 it was comparatively rare. Examination of stomachs, however, did not show that the megalopas were feeding on the diatom. The presence of many other species of plankton organisms at the surface amongst these Corystes megalopas was marked (see Table III) ; certain young fish which normally live deep down were also on the surface on this occasion (23, p. 109). Gurney says (11, p. 464) that the megalopa does not seem to be a pelagic form properly speaking, and was only once obtained in the tow-net, and then within a fathom or so of the bottom, in deep water.

Seasonal distribution. It is obvious from the above results that Corystes megalopas were most abundant in mid-May ; after May 19th none were captured.

It would be interesting to know whether this was the same shoal that was met with on April 8th, when the Corystes were then in the later zoea stages. It is, at any rate, an indication that the larvæ must have some considerable powers of keeping together if, when they have passed through all the stages of their pelagic existence, they can form so large a shoal as that met with on May 19th, 1925. Gurney (14, p. 39) says: "It is not very unusual to find swarms of the larvæ of one species in different stages of development, which seems to indicate a power of keeping together from hatching onwards, or of collecting in a suitable locality." He mentions such a swarm of Corystes zoeas at Plymouth.

\section{STOMATOPODA.}

Alima larve of Squilla Desmaresti Risso.

These larvæ were present on two days, July 29th and August 6th, the catches being -

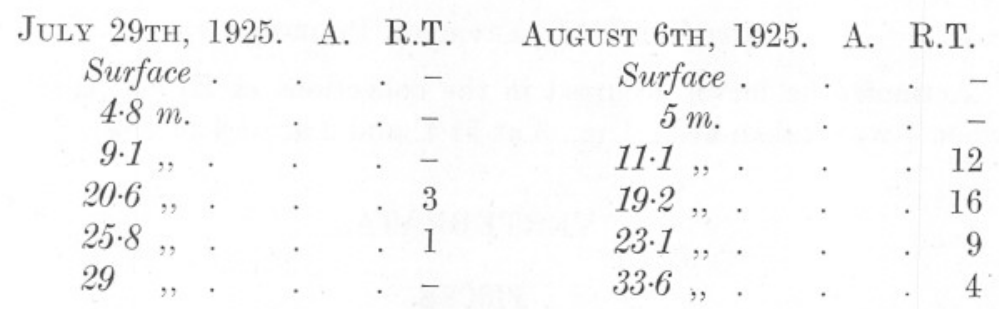

Thus it is seen that the larvæ, which consisted of stages 1, 2, 3, and 4 (Giesbrecht, 7 ) in equal numbers and of one stage 5 , appeared to have their maximum abundance between 10 and 25 metres, being absent from the surface and 5-metre layers. 
Giesbrecht ( $\%$, p. 226), in connection with the vertical distribution of this species in the Mediterranean, says that the pelagic larvæ of Squilla sp. (Alima) were only occasionally met with in the surface catches, most of them occurring in the collections made with nets with 50 to 200 metres of wire out. According to Chun (2, p. 29) Alima stages were chiefly at a depth of $40-100 \mathrm{~m}$. It is to be expected that in this region they would be higher in the water than in the Mediterranean.

\section{MOLLUSCA.}

Echinospira LaRvæ of Lamellaria sp.

Echinospira larvæ, when present, always occurred below a depth of 10 metres. They were never captured at levels above this depth.

\section{Purpura lapillus (Linnæus).}

Young stages of this species occurred once in the plankton, when nine were taken at $22 \cdot 1$ metres on April 22nd, at E1.

\section{Limacina RETroversa (Flemm.).}

When present Limacina were taken from depths below 10 metres.

Paulsen (21 a, p. 57) says, "As a whole, L. retroversa is a surfaceorganism, found most frequently at or near the surface of the sea. In many cases it is common from the surface to a depth of about $50 \mathrm{~m}$." $\mathrm{He}$ also gives records from greater depths, and he further remarks, "When the sun is high in the sky, the species is sometimes not met with at the surface in great quantities, but lives in a depth 5-75 m., but when the sun is low large shoals can be taken at the very surface."

\section{PHORONIDEA.}

Actinotrocha larve of Phoronis sp.

Actinotrocha larvæ occurred in the collections at E1 on April 22nd, when 4 were taken at $22 \cdot 1 \mathrm{~m} ., 3$ at $51 \cdot 4$, and 2 at $61 \cdot 4$ metres.

\section{VERTEBRATA.}

\section{PISCES.}

Pelagic eggs of Teleostean fishes occurred in fair quantities, but on account of the difficulty of identifying preserved eggs they have not been dealt with. The vertical distribution shown by the pelagic young of teleostean fishes has been dealt with in a previous paper (23). 


\section{SUMMARY.}

1. The vertical distribution of many species in daylight in the Plymouth area is shown, as a result of the examination of a number of serial hauls taken with the stramin ring-trawl between the dates April 2nd and August 6th, 1926.

2. It is shown that probably the errors introduced by the employment of a non-closing net are for the present purpose negligible.

3. The indications are that most species have an optimum level at which they live, in the daytime, the actual depth varying from day to day according to weather and other conditions.

4. A few species appear to show no preference, being present equally abundantly at all depths or showing marked changes in the region of greatest abundance from day to day.

5. A provisional list is given on page 567, showing the order in which many of the different species appear in greatest abundance from the surface downwards.

6. The vertical distribution appears to differ for the two sexes of Calanus finmarchicus, the males tending to avoid the surface layers more than the females.

7. The presence of the medusa Cosmetira pilosella in fair numbers in a catch in the daytime in the Plymouth region would seem to be a reliable indication that the net has been fishing below 20 metres.

8. A catch of Calanus finmarchicus made by the stramin ring-trawl consists nearly always of over 80 per cent adults.

9. No attempt has been made definitely to correlate behaviour with external factors : more observations are to be desired.

10. Brief notes are given on the seasonal distribution of various species. The danger of drawing conclusions about seasonal abundance from daylight hauls only is shown by the results for Tomopteris helgolandica (p. 575).

\section{LITERATURE CITED.}

1. Bouvier, E. L. Recherches sur le Développement post-embryonnaire de Langouste commune (Palinurus vulgaris). Journ. Mar. Biol. Assoc., N.S., Vol. X., No. 2, p. 179. 1914.

2. Chun, C. Die pelagische Thierwelt in grösseren Meerestiefen und ihre Beziehungen zu der Oberflächenfauna. Bibliotheca Zoologica, Heft 1. Cassel. 1887.

3. Cunningham, J. T. On the Development of Palinurus vulgaris, the Rock Lobster or Sea Crayfish. Journ. Mar. Biol. Assoc., N.S., Vol. II, p. 141. 1891-92.

NEW SERIES. - VoL. XIV. No. 3. MARCH, 1927. 
4. Damas, D. Notes Biologiques sur les Copépodes de la Mer Norvégienne. Conseil. Internat. pour l'Explor. de la Mer. Publ. de Circ., No. 22. 1905.

5. Farran, G. P. Copepoda. Cons. Perm. Intern. pour l'Expl. de la Mer. Bull. Trimestr. Deux. Pt. 1911.

6. Farran, G. P. Biscayan Plankton collected during a Cruise of H.M.S. Research, 1900. Pt. XIV. The Copepoda. Journ. Linn. Soc., Zool., Vol. XXXVI. April, 1926.

7. Giesbrecht, W. Stomatopoden. Fauna und Flora des Golfes von Neapel. Berlin, 1910.

8. Gough, L. H. Report on the Plankton of the English Channel in 1903. Mar. Biol. Assoc. Intern. Fish. Invest., 1902-3. Southern area, 1905.

9. Grax, H. H. Das Plankton des Norwegischen Nordmeeres. Rep. Norweg. Fish. Mar. Invest., Vol. II, Pt. II, 1909. No. 5 (1902).

10. Grobben, C. Die Entwicklungsgeschichte von Cetochilus Septentrionalis Goodsir. Arbeiten aus dem Zoologischen Institute der Universität, Wien. Vol. III, Pt. 3. 1881.

11. Gurney, R. The Metamorphosis of Corystes cassivelaunus (Pennant). Quart. Journ. Micr. Sci., Vol: 46, N.S., 1903, p. 461.

12. Gurney, R. The larval stages of Processa canaliculata Leach. Journ. Mar. Biol. Assoc., N.S., Vol. XIII, No. 1, p. 245. 1923.

13. Gurney, R. Some Notes on Leander longirostris M. Edwards, and other British Prawns. Proc. Zool. Soc., London, 1923, I, p. 97.

14. Gurney, R. British Antarctic ("Terra Nova") Expedition, 1900. Natural History Report. Zoołogy, Vol. VIII, No. 2, Crustacea. Pt. IX. Decapod Larvæ. 1924.

15. Kraefft, F. Über das Plankton in Ost-und Nordsee und den Verbindungsgebieten, mit besonderer Berüchsichtigung der Copepoden. Wiss. Meeresunter. Kiel, XI, 1910, p. 79.

16. Lebour, M. V. Stages in the Life History of Calanus finmarchicus (Gunnerus), Experimentally Reared by Mr. L. R. Crawshay in the Plymouth Laboratory. Journ. Mar. Biol. Assoc., N.S. Vol. XI, 1916-18, p. 1.

17. Lebour, M. V. The Microplankton of the Plymouth Sound from the Region beyond the Breakwater. Journ. Mar. Biol. Assoc., N.S., Vol. XI, 1916-18, p. 133. 
18. Lebour, M. V. The Euphausiidæ in the Neighbourhood of Plymouth and their Importance as Herring Food. Journ. Mar. Biol. Assoc., N.S., Vol. XIII, No. 2, 1924, p. 402.

19. McIntosh, W. C. Notes from the Gatty Marine Laboratory, St. Andrews. No. XLVII. 1. A Contribution to the British Tomopteridæ. Ann. Mag. Nat. Hist., Ser. 9, Vol. XV, p. 1. 1925.

20. Malaquin, A., and Carin, F. Tomoptérides provenant des Campagnes de l'Hirondelle et de la Princesse-Alice (1888-1910). Résult. Camp. Sci. Albert 1er., Monaco. Fasc. LXI. 1922.

21. Paulsen, O. Studies on Biology of Calanus finmarchicus. Medd. fra Komm. Havund. Plankton, Bd. I, Nr. 4. 1906.

21 a. Paulsen, O. Pteropoda. Cons. Intern. Perm. pour l'Explor. de la Mer. Bull. Trim., Pt. I. 1910.

22. Russeld, F. S. The Vertical Distribution of Marine Macroplankton. An Observation on Diurnal Changes. Journ. Mar. Biol. Assoc., N.S., Vol. XIII, No. 4, p. 769.1925.

23. Russell, F. S. The Vertical Distribution of Marine Macroplankton, II. The Pelagic Young of Teleostean Fishes in the Daytime in the Plymouth Area, with a note on the Eggs of Certain Species. Journ. Mar. Biol. Assoc., N.S., Vol. XIV, No. 1, p. 101, 1926.

24. Russell, F. S. The Vertical Distribution of Marine Macroplankton, III. Diurnal Observations on the Pelagic Young of Teleostean Fishes in the Plymouth Area. Journ. Mar. Biol. Assoc., Vol. XIV, No. 2, p. 387. 1926.

25. Russell, F. S. The Vertical Distribution of Marine Macroplankton IV. The Apparent Importance of Light Intensity as a Controlling Factor in the Behaviour of Certain Species in the Plymouth Area. Journ. Mar. Biol. Assoc., N.S., Vol. XIV, No. 2, p. 415. 1926.

26. Savage, R. E. The Plankton of a Herring Ground. Min. Agric. Fish. Invest., Ser. II, Vol. IX, No. 1. 1926.

27. Southern, R. Polychæta of the Coasts of Ireland, III. The Alciopinæ, Tomopteridæ, and Typhloscolecidæ. Department of Agriculture and Technical Instruction for Ireland. Fisheries Branch Sci. Invest., 1910, No. III.

28. Wiтн, C. Copepoda, I. Calanoida Amphascandria. Danish Ingolf Expedition, Vol. III, No. 4. 1915.

29. Wolfenden, R. N. Notes on the Copepoda of the North Atlantic Sea and the Faeröe Channel. Journ. Mar. Biol. Assoc., N.S., Vol. VII, 1904-6, p. 110. 


\section{TABLE II.}

\section{Showing Total Numbers of Organisms in 10-Minute Hauls at each Depth.}

July 16 th, 1925.

Anomalocera Patersoni

Leander sp. larvæ .

Calanus finmarchicus

Crab zoea

Upogebia sp. larvæ

Crab megalopa

Centropages typicus

Sagitta bipunctata

Pleurobrachia pileus

Phialidium sp.

Obelia sp.

Turris pileata

Podon intermedius

Evadne Nordmanni

Isias clavipes

Pandalid larvæ

Nyctiphanes furcilia

Porcellana sp. zoea .

Galatheid larvæ

Callianassa larvæ

Cosmetira pilosella

Candacia armat

Apherusa sp.

Pagurid larvæ

Saphenia gracilis .

Young mysid

Tomopteris helgolandica

Crangonid larvæ

Ebalia sp. zoea

Metridia lucens

Temora longicornis

Nyctiphanes Couchii

Palinurus phyllosoma

Galatheid post-larvæ

Porcellana sp. post-larva

Upogebia sp. post-larva.

Young Æquorea Forskalia

Adult mysids .

Caligus rapax

Bougainvillea sp.

Ebalia sp. megalopa

Pagurid glaucothoë

Pœcilochætus larvæ.
A. Closing Metre Net.

Surface. $2 \cdot 7 \mathrm{~m} . \quad 6 \cdot 5 \mathrm{~m} .25 \cdot 8 \mathrm{~m} .26 \cdot 8 \mathrm{~m} . \quad 41.8 \mathrm{~m}$.

$\begin{array}{rrrrrr}291 & 123 & 101 & 12 & 6 & 3 \\ 2 & 4 & - & - & - & - \\ 17,640 & 28,540 & 59,220 & 13,900 & 21,680 & 6,880 \\ 5,740 & 1,920 & 3,860 & 2,280 & 2,380 & 4,320 \\ 900 & 840 & 2,300 & 2,380 & 380 & 180 \\ 380 & 60 & 60 & 120 & 100 & 60 \\ 5,860 & 11,560 & 21,680 & 6,980 & 6,080 & 1,840 \\ 1,080 & 5,860 & 8,460 & 10,940 & 15,360 & 21,280 \\ 81 & 11 & 27 & 28 & 36 & 25 \\ 60 & 6,520 & 3,760 & 780 & 20 & 2,940 \\ - & 160 & 2,720 & 2,040 & - & 180 \\ - & 1 & 2 & 29 & 293 & 125 \\ - & 60 & 420 & 2,720 & 1,460 & 760 \\ - & 40 & 80 & 200 & 40 & 20 \\ - & - & 40 & 40 & 20 & 20 \\ - & - & 20 & 360 & 960 & 620 \\ - & - & 100 & 140 & 40 & 100 \\ - & - & - & 140 & 120 & 420 \\ - & - & - & 700 & 740 & 220 \\ - & - & - & 1,520 & 3,760 & 2,280 \\ - & - & - & 110 & 14 & 108 \\ - & - & - & 40 & 180 & 40 \\ - & - & - & 3,480 & 6,480 & 6,940 \\ - & - & - & 180 & 480 & 540 \\ - & - & - & 11 & - & 32 \\ - & - & - & 200 & 100 & 840 \\ - & - & - & 14 & 17 & 169 \\ - & - & - & 80 & 120 & 100 \\ - & - & - & 140 & 200 & 720 \\ - & - & - & 20 & 20 & 20 \\ 40 & 40 & - & 5,820 & 11,320 & 29,820 \\ - & - & - & 4 & 25 & 63 \\ - & - & - & 1 & 1 & 6 \\ - & - & - & 20 & - & - \\ - & - & - & 60 & 40 & 80 \\ - & - & - & 1 & 1 & 4 \\ - & - & - & 3 & - & 1 \\ - & - & - & - & 1 & 21 \\ - & - & - & - & 2 & 2 \\ - & - & - & - & - & 4 \\ - & - & - & - & 3 \\ - & - & - & - & 2\end{array}$


TABLE III.

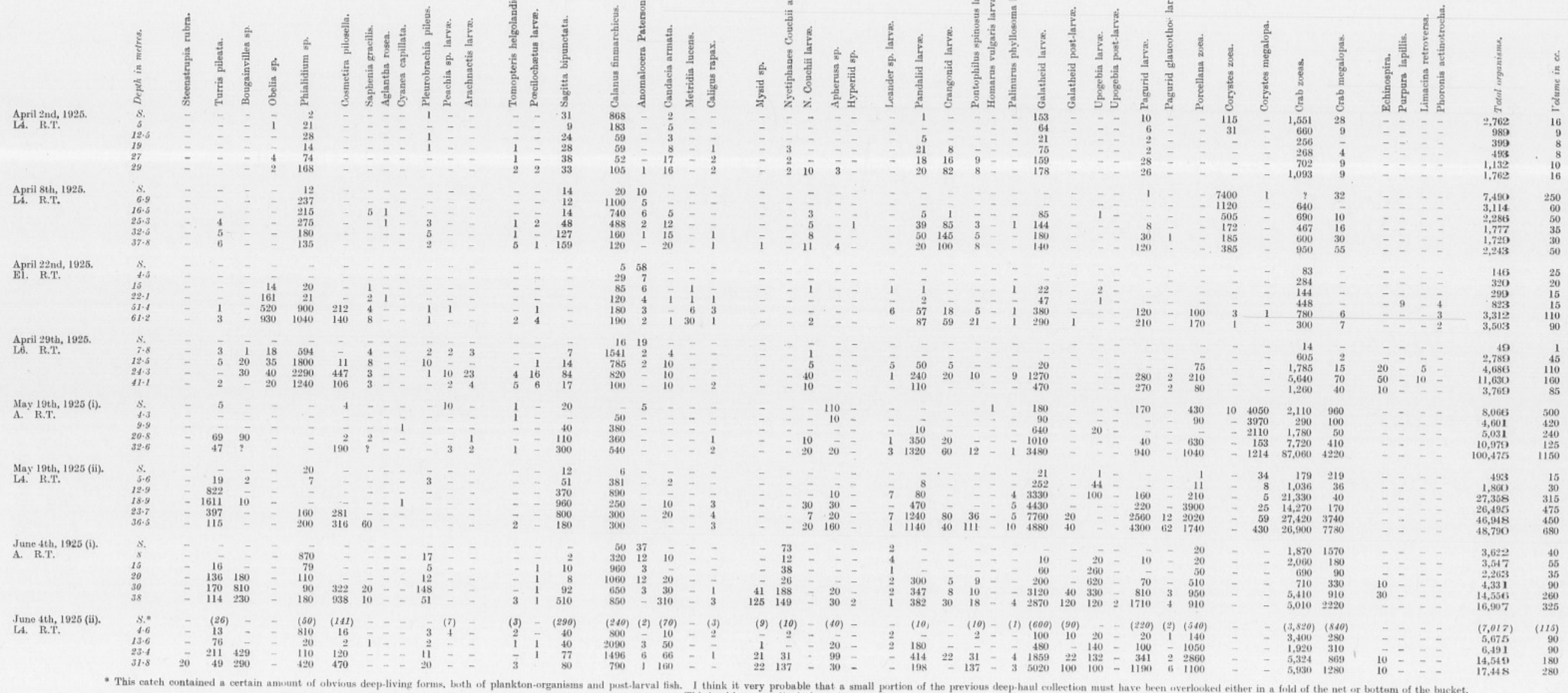


